\title{
Influence of plastic fines content on the liquefaction susceptibility of sands: monotonic loading
}

\author{
Meisam Goudarzy ${ }^{1} \cdot$ Debdeep Sarkar $^{1}$ (D) $\cdot$ Wolfgang Lieske $^{1} \cdot$ Torsten Wichtmann $^{1}$
}

Received: 29 August 2020 / Accepted: 20 June 2021 / Published online: 28 July 2021

(C) The Author(s) 2021

\begin{abstract}
The paper presents an experimental study on the effect of plastic fines content on the undrained behavior and liquefaction susceptibility of sand-fines mixtures under monotonic loading. The results of undrained monotonic triaxial compression tests conducted on mixtures of Hostun sand with varying amount (0-20\%) and type (kaolin and calcigel bentonite) of plastic fines are presented. The specimens were prepared with different initial densities using the moist tamping method and consolidated at two different isotropic effective stresses. The results demonstrate that for both types of plastic fines, an increase in the fines content leads to a more contractive response and lower values of mobilized deviatoric stress. Despite similar relative density and fines content, the sand-kaolin mixtures showed a more contractive behavior than the sandcalcigel specimens. The steady-state lines (SSLs) in $e-p$ space generally move downwards with increasing clay content. While the slopes of the SSLs for the clean Hostun sand and the mixtures with 10 and 20\% kaolin are quite similar, the SSL lines for the specimens containing $10 \%$ or $20 \%$ calcigel run steeper or flatter, respectively. The inclination of the SSL in the $q-p^{\prime}$ plane was found independent of clay type and content. The sand-kaolin mixtures were observed to be more susceptible to instability and flow liquefaction than the sand-calcigel mixtures.
\end{abstract}

Keywords Instability line $\cdot$ Plastic fines content $\cdot$ Sand-fines mixtures $\cdot$ Steady-state line $\cdot$ Undrained monotonic triaxial tests

\section{Introduction}

The effect of various parameters on the behavior of granular soils under undrained loading conditions is of particular interest for the design of foundations or other geotechnical structures in earthquake-prone regions and has thus been studied by numerous researchers. It is well known that water-saturated loose cohesionless soils are

Debdeep Sarkar

debdeep.sarkar@rub.de

Meisam Goudarzy

meisam.goudarzyakhore@rub.de

Wolfgang Lieske

wolfgang.lieske@rub.de

Torsten Wichtmann

torsten.wichtmann@rub.de

1 Chair of Soil Mechanics, Foundation Engineering and Environmental Geotechnics, Ruhr-Universität Bochum, Bochum, Germany very susceptible to liquefaction under undrained static or cyclic loading. However, there is strong evidence suggesting that a fines content (defined as $\%$ finer than $0.063 \mathrm{~mm}$ ) can even increase the susceptibility to liquefaction. A certain portion of the fines embedded in a host sand forms a part of the soil's structure and thus contributes directly or indirectly to the evolution of force chains within the skeleton of grains, influencing the soil behavior under various loading conditions. The majority of previous research was dedicated to the influence of non-plastic fines on various properties of granular soils under monotonic, cyclic or dynamic loading that means silty sands were tested in these studies (e.g., [8, 18, 26, 27, 29, 32-34, 38, $48,49,51-54,61,64,66-70]$ and the references therein). The influence of plastic fines has attracted less attention, mainly due to the fact that for a long time, granular soils with plastic fines were considered to possess a lower liquefaction susceptibility.

Site inspections have shown that also clayey sands are prone to liquefaction during earthquakes. For instance, the 
Chi-Chi earthquake $\left(M_{w}=7.6\right)$ of 1999 triggered extensive soil liquefaction in Central Western Taiwan. The majority of the sand deposits in this region were characterized with significant amounts of low-to-medium plastic fines [12]. Similar observations for different sites and earthquakes were previously reported by Ishihara et al. [25], Holzer et al. [24] and Miura et al. [37]. The available literature on the effect of plastic fines on the behavior of granular soils under monotonic and cyclic loading is summarized in the following, discussing the influence of the content of fines first, followed by the effect of fines plasticity.

a) Effect of clay content

The effect of the clay content on the mechanical behavior of sand depends on several factors, including the grading of the sand, the content and type of the clay, the distribution of the clay within the soil and the chemistry of the pore water [23, 26, 28, 46].

Seed et al. [58] studied the influence of clay content of granular soils using data from several case histories in China. It was concluded that in the majority of the liquefaction events, the ground was composed of sands with a clay content lower than $15 \%$, where the clay had a liquid limit $w_{\mathrm{L}}$ less than $35 \%$ and a natural water content higher than 0.9 times the liquid limit. Based on several liquefaction reports in the late 1980s and 1990s, Andrews and Martin [4] supported the applicability of the criterion of Seed et al. [58]. A clay content larger than $15 \%$ was typically found to increase the liquefaction resistance. Georgiannou et al. [17] studied the behavior of clayey sand during undrained static shear in triaxial compression and extension. The specimens were prepared by sedimenting Ham river sand in a kaolin suspension. For a given granular void ratio, as the clay content of the mixture increased from 4.6 to $10 \%$, the undrained softening got more pronounced and the strains up to phase transformation increased, when the specimens were sheared in compression. Furthermore, in the specimens with a clay content of $7.6 \%$, the deviator stress at phase transformation was 1.7 times lower than for the specimens with a clay content of $4.6 \%$. However, a reverse in this trend at clay fractions beyond $20 \%$ was noted. At a clay content of $30 \%$, no dilative tendency was observed anymore and undrained softening was less pronounced than at lower clay content. Koester [28], Kuwano et al. [30] and Perlea [46] concluded an increase in the static liquefaction resistance of clayey soils in case of a clay content exceeding $20 \%$. Ni et al. [41] investigated sand-clay and sand-silt mixtures in undrained static triaxial tests and analyzed their results in the context of published data.
They concluded that for normally consolidated samples, the presence of a certain amount of clay $\left(f_{c}=9 \%\right)$ between the sand grains causes a reduction in strength. Through undrained static triaxial tests on sand-clay mixtures, Bouferra and Shahrour [10] observed a reduction in the liquefaction resistance with increasing clay content up to $f_{\mathrm{c}}=15 \%$. However, a reversal of this trend was recognized in the tests on the specimens with $f_{\mathrm{c}}=20 \%$, which showed a recovery of the soil dilatancy and consequently an increase in the soil resistance. A similar tendency was reported by Beroya et al. [9] for silt-clay mixtures although previously Guo and Prakash [23] concluded no definite criterion for evaluating the liquefaction potential of such clayey soils solely based on the amount of clay content.

Some studies have also investigated the influence of plastic fines content on the cyclic behavior of sand-fines mixtures. Through undrained cyclic triaxial tests, Perlea et al. [45] found that a low amount of clayey fines $(<15 \%)$ decreased the liquefaction resistance, while an addition of more than $20 \%$ fines resulted in an enhancement. In contrast, Polito [47] reported the cyclic resistance of sands with plastic fines to be relatively independent of fines content, clay type, water content and liquidity index, based on a series of cyclic triaxial tests on mixtures of Yatesville and Monterey sands with kaolinite and bentonite. Nabeshima et al. [39] tested Toyoura sand mixed with kaolin at constant relative densities in cyclic torsional shear tests under undrained conditions. It was found that the addition of kaolin clay to the sand caused a weakening of the soil skeleton, promoting a flow liquefaction and leading to a reduction in the cyclic resistance. Ghahremani et al. [19] conducted two series of undrained cyclic triaxial tests on sand containing a certain amount of either kaolin or bentonite. For both types of clay, they found a trend being opposite to that observed in previous studies: The liquefaction potential increased with increasing clay content for fines up to $30 \%$, beyond which the addition of more fines caused a reduction in the liquefaction potential. Tsai et al. [63] investigated the effect of plastic fines $\left(f_{\mathrm{c}}=17-61 \%\right)$ on the liquefaction resistance of dry-deposited mixtures of clean sand and clay with plasticity index $I_{\mathrm{P}}=22 \%$. They also found an increase in the liquefaction resistance due to the presence of plastic fines.

b) Effect of plasticity index of clay fraction

Some studies have also investigated the effect of the plasticity of the clayey fines, described by the plasticity index, $I_{\mathrm{P}}$, on the liquefaction susceptibility 
of the granular host soil. Very few studies dealt with the shear strength and liquefaction resistance under static loading conditions, while the majority concentrates on the cyclic liquefaction behavior. A relatively recent study was conducted by Papadopoulou and Tika [43] using a clean well-rounded sand as the base material. To obtain fines with different plasticity a non-plastic silt $\left(I_{\mathrm{P}}=0 \%\right)$ and speswhite kaolin $\left(I_{\mathrm{P}}=35 \%\right)$ were mixed and the specimens were prepared using moist tamping. At a given void ratio and fines content, an increase in contractiveness with increasing $I_{\mathrm{P}}$ was noted till a certain threshold value, after which specimens with higher $I_{\mathrm{P}}$ values exhibited dilatancy. For their tested materials, the threshold $I_{\mathrm{P}}$ for $5 \%$ and $15 \%$ fines content was found to be $6 \%$ and $22 \%$, respectively.

Based on results from a series of undrained cyclic triaxial tests on different mixtures of sand with plastic fines, Ishihara [26] concluded that an increase in the plasticity index of the fine material will increase the cyclic strength of the mixture. On the contrary, using cyclic triaxial tests on moist-tamped specimens of sand-fines mixtures $\left(f_{\mathrm{c}}=5-60 \%\right)$, Koester [28] showed that the undrained cyclic strength was not uniquely related to the plasticity index of the fines fraction for $f_{\mathrm{c}}<45 \%$. However, the undrained cyclic strength increased with increasing plasticity of fines in specimens containing $60 \%$ fines. Generally, the effect of the plasticity index of the fines on the undrained cyclic strength was found to be significantly less pronounced than the effect of the gradation of the host material. From cyclic ring shear tests, Gratchev et al. [21] reported a significant increase in the liquefaction resistance of sand when mixed with bentonite. The effect of adding kaolin or illite was smaller, which was attributed to their lower plasticity. Through cyclic tests on Firouzkooh sand mixed with kaolin and bentonite fines, Ghahremani et al. [19] also found that the liquefaction resistance increased with increasing plasticity of the fines, similar to the observations reported by Ajmera et al. [3]. Park and Kim [44] studied the liquefaction resistance of moist-tamped specimens of a sand mixed with $10 \%$ plastic fines with varying plasticity in the range $I_{\mathrm{P}}=8-377 \%$. They found that the liquefaction resistance of loose specimens was marginally influenced by the plasticity of the fines. However, in the case of dense specimens, liquefaction resistance decreased up to $40 \%$ as $I_{\mathrm{P}}$ of the clayey fines increased which is in contrast to the studies mentioned previously.

It may be concluded that the literature is contradictory regarding both the influence of the content and the plasticity of clayey fines on the undrained monotonic and cyclic behavior of sand-clay mixtures. The conflicting results between the various studies may be due to differences in the characteristics of the used host sands and fines, the basis of comparison (e.g., similar relative density or void ratio), the sample preparation method (moist tamping vs. pluviation techniques) or the type of test. In particular, only a limited number of studies have investigated the combined effect of clay content and plasticity on the liquefaction susceptibility and steady/critical state characteristics of sand-clay mixtures under monotonic loading. Therefore, in the current paper, undrained static triaxial tests on mixtures of a host sand with two different clays having different mineralogical composition are analyzed to gain a deeper understanding into the engineering properties of sand-clay mixtures under monotonic loading. The results of cyclic tests on the same mixtures will be presented later in a companion paper.

\section{Experimental program}

\subsection{Tested materials}

In the present study, three different base materials were used, from which the four different sand-clay mixtures were prepared: Hostun sand as host sand and kaolin and calcigel bentonite as plastic fines.

Hostun sand is a poorly graded medium quartz sand with grain sizes ranging from 0.1 to $1.0 \mathrm{~mm}$ (mean grain size $d_{50}=0.33 \mathrm{~mm}$, uniformity coefficient $C_{\mathrm{u}}=d_{60} /$

Table 1 Physical characteristics of the adopted fine materials

\begin{tabular}{llll}
\hline & & $\begin{array}{l}\text { Amberg } \\
\text { kaolin } \\
\text { Kaolinite }\end{array}$ & $\begin{array}{l}\text { Calcigel } \\
\text { bentonite } \\
\text { Montmorillonite }\end{array}$ \\
\hline Liquid limit $w_{\mathrm{L}}$ & $\%$ & 56.1 & 103.1 \\
$\begin{array}{l}\text { Plastic limit } w_{\mathrm{P}} \\
\text { Plasticity index } I_{\mathrm{P}}\end{array}$ & $\%$ & 38.0 & 43.3 \\
$\begin{array}{l}\text { Specific gravity } \\
\text { Cation exchange }\end{array}$ & - & 19.1 & 58.8 \\
$\begin{array}{c}\text { capacity }(\mathrm{CEC})^{\#} \\
\text { Specific surface }\end{array}$ & $100 \mathrm{~g}$ & 2.64 & 2.79 \\
$\begin{array}{l}\text { area } \\
(\mathrm{SSA})^{\circ}\end{array}$ & & 32 & 64 \\
\hline
\end{tabular}

${ }^{\#} \mathrm{Cu}$-Triethylenetetramine [36] ${ }^{\circ}$ Ethylene glycol monoethyl ether (EGME) [11] 
$\left.d_{10}=1.58\right)$. The values of maximum and minimum void ratio, $e_{\max }$ and $e_{\min }$, are 1.04 and 0.67 , respectively [20]. An image analysis of microscopic photographs of randomly selected particles gave average values of roundness and sphericity of 0.40 and 0.75 , respectively [55]. In order to investigate the influence of fines content in a broad range of plasticity, two types of clays were used in this study. Amberg kaolin is a natural kaolinite clay with a plasticity index of $I_{\mathrm{P}}=19.1 \%$. Calcigel bentonite is a montmorillonite clay with dominantly calcium as exchangeable cation and a plasticity index of $58.8 \%$. Since it has been considered as a possible component of engineered barriers for underground nuclear waste repositories, several studies have been devoted to this clay (e.g., $[2,5])$. The physical characteristics of the adopted fines are shown in Table 1. According to DIN 18196 [16], since both clays have a liquid limit $w_{\mathrm{L}}>50 \%$, they can be classified as highly plastic. The grain size distribution curves of the three materials are shown in Fig. 1.

To prepare the sand-clay mixtures, the dry sand and dry clay powder were mixed in the corresponding proportions ( $10 \%$ and $20 \%$ clay content by weight). The mixing was done by hand until a homogeneous distribution of both components was achieved. Afterward, water was added to the mixture. The water contents used for the preparation of the triaxial samples of the different mixtures are given in Table 2. After the addition of water, a second mixing process was carried out by hand in order to achieve a homogeneous distribution of the water content in the mixture. The mixtures were then left in a sealed container for at least $12 \mathrm{~h}$ before the samples were prepared in the corresponding test device.

To calculate the relative density $I_{\mathrm{D}}$ according to Eq. (1), the void ratios in the loosest and densest possible states, $e_{\max }$ and $e_{\min }$, of the material are required.

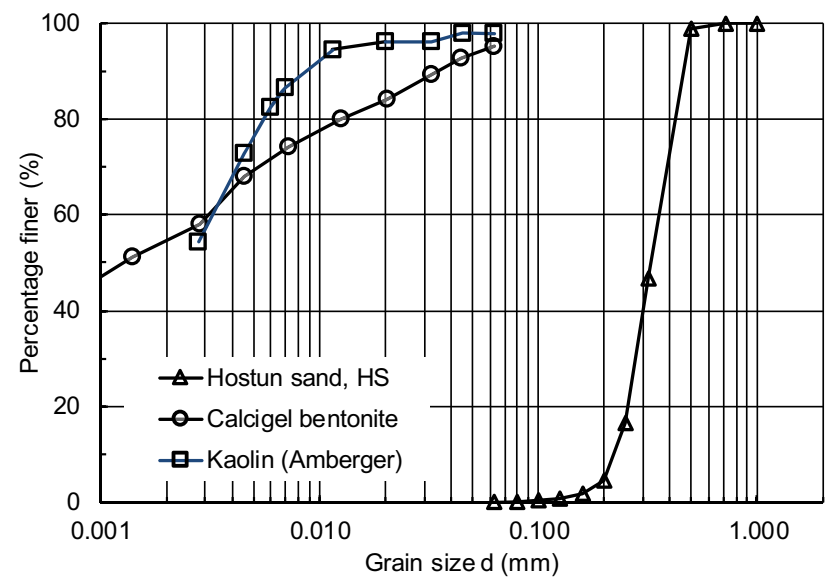

$I_{D}=\frac{e_{\max }-e}{e_{\max }-e_{\min }}$

For non-cohesive soils, the determination of the loosest and densest states is described in DIN 18126 (1996) [14]. However, for an application of the specified procedures, the maximum allowable content of the fine fraction (grain sizes $\mathrm{d}<0.063 \mathrm{~mm}$ ) is limited. The method for the loosest state (funnel deposition of dry sand) should not be applied to sands with fines contents larger than $15 \%$. The applicability of the procedure for the densest state by means of the impact test (layerwise compaction of the water-saturated soil by strokes applied against the mold using a special tool) is restricted to clean sands only, while a maximum content of $15 \%$ fines is allowed in case of the vibrating table test. However, several studies in the literature have applied the same methods also for higher fines contents (e.g., [20, 59]), mainly due to the lack of alternative methods applicable for these fines contents. Likewise, also in the present study the loosest state was determined according to DIN 18126 (1996) for all mixtures, although the maximum fines content of $20 \%$ in the mixtures exceeds the limiting fines content of $15 \%$. For the densest state, two approaches were followed: (1) Proctor tests following DIN 18127 [15], and (2) impact tests according to DIN 18126. While the original procedure defined in DIN 18126 is carried out on water-saturated sand, the impact tests of the present study were performed on dry materials, as the addition of water leads to sticking or segregation of the sand and clay particles in the tested mixtures and therefore would not have been appropriate. The results of the tests on $e_{\max }$ and $e_{\min }$ are shown in Fig. 2. In these tests, beside $f_{\mathrm{c}}=0 \%, 10 \%$ and $20 \%$ the fines contents $f \mathrm{c}=5 \%$ and $25 \%$ were tested additionally. Evidently, the differences between the kaolin-sand mixtures and the calcigel-sand mixtures in terms of $e_{\max }$ and $e_{\text {min }}$ increase with increasing clay content, with higher values for the mixtures containing kaolin. In addition, differences between the two types of tests for the determination of the minimum void ratio can be seen. For clay contents exceeding $10 \%$, denser packings can be reached by the Proctor test than by the impact test. Therefore, the minimum void ratio corresponding to the densest state has been adopted from the results of the Proctor tests rather than the standard impact tests. Additionally, the fabric obtained via the compaction method in the Proctor test is assumed to be similar to the fabric of the triaxial specimens prepared by moist tamping, which may be regarded as another argument for selecting the $e_{\min }$ values from the Proctor tests. For the clean Hostun sand, the determination of $e_{\max }$ and $e_{\min }$ was carried out in accordance with DIN 18126 (1996).

Fig. 1 Grain size distribution of the adopted materials 
Table 2 Summary of the performed static triaxial tests

\begin{tabular}{|c|c|c|c|c|c|c|c|}
\hline Test & Clay type & $\begin{array}{l}\text { Clay content } \\
(\%)\end{array}$ & $\begin{array}{l}\text { Initial water content } \\
(\%)\end{array}$ & $\begin{array}{l}I_{\mathrm{D} 0} \\
(-)\end{array}$ & $\begin{array}{l}e_{0} \\
(-)\end{array}$ & $\begin{array}{l}p_{0}^{\prime} \\
(\mathrm{kPa})\end{array}$ & $\begin{array}{l}B \text {-value } \\
(-)\end{array}$ \\
\hline TS-HS-1 & - & 0 & 9 & 0.13 & 1.009 & 100 & 0.97 \\
\hline TS-HS-2 & - & 0 & 9 & 0.29 & 0.949 & 100 & 0.95 \\
\hline TS-HS-3 & - & 0 & 9 & 0.38 & 0.912 & 100 & 0.99 \\
\hline TS-HS-4 & - & 0 & 9 & 0.61 & 0.819 & 200 & 0.98 \\
\hline TS-10Cal-1 & Calcigel & 10 & 14 & 0.40 & 0.87 & 100 & 0.99 \\
\hline TS-10Cal-2 & Calcigel & 10 & 14 & 0.43 & 0.853 & 200 & 0.99 \\
\hline TS-10Cal-3 & Calcigel & 10 & 14 & 0.54 & 0.802 & 200 & 0.99 \\
\hline TS-10Cal-4 & Calcigel & 10 & 14 & 0.55 & 0.798 & 200 & 0.98 \\
\hline TS-10Cal-5 & Calcigel & 10 & 14 & 0.60 & 0.771 & 100 & 0.99 \\
\hline TS-10Cal-6 & Calcigel & 10 & 14 & 0.61 & 0.767 & 200 & 0.98 \\
\hline TS-20Cal-1 & Calcigel & 20 & 18 & 0.51 & 0.793 & 100 & 0.99 \\
\hline TS-20Cal-2 & Calcigel & 20 & 18 & 0.57 & 0.763 & 200 & 0.97 \\
\hline TS-20Cal-3 & Calcigel & 20 & 18 & 0.66 & 0.722 & 100 & 0.99 \\
\hline TS-20Cal-4 & Calcigel & 20 & 18 & 0.69 & 0.704 & 200 & 0.99 \\
\hline TS-20Cal-5 & Calcigel & 20 & 18 & 0.83 & 0.637 & 200 & 0.99 \\
\hline TS-10Као-1 & Kaolin & 10 & 8 & 0.49 & 0.885 & 100 & 0.99 \\
\hline TS-10Као-2 & Kaolin & 10 & 8 & 0.65 & 0.79 & 200 & 0.98 \\
\hline TS-10Као-3 & Kaolin & 10 & 8 & 0.72 & 0.744 & 200 & 0.98 \\
\hline TS-10Као-4 & Kaolin & 10 & 8 & 0.73 & 0.738 & 100 & 0.99 \\
\hline TS-10Као-5 & Kaolin & 10 & 8 & 0.80 & 0.696 & 200 & 0.98 \\
\hline TS-20Као-1 & Kaolin & 20 & 14 & 0.75 & 0.681 & 100 & 0.99 \\
\hline TS-20Као-2 & Kaolin & 20 & 14 & 0.80 & 0.638 & 200 & 0.99 \\
\hline TS-20Као-3 & Kaolin & 20 & 14 & 0.81 & 0.622 & 200 & 0.98 \\
\hline TS-20Као-4 & Kaolin & 20 & 14 & 0.88 & 0.561 & 250 & 0.98 \\
\hline TS-20Kao-5 & Kaolin & 20 & 14 & 0.92 & 0.522 & 200 & 0.97 \\
\hline
\end{tabular}

\subsection{Test device}

The monotonic triaxial tests were carried out on a Wykeham Farrance Eng. Ltd. (England) loading machine as adopted in previous studies, e.g., by Sarkar et al. [56]. The loading was applied at a constant displacement rate of $0.225 \mathrm{~mm} / \mathrm{min}$. The vertical force was measured by a load cell mounted externally on the crosshead. The vertical deformation was recorded by a displacement transducer, LVDT, mounted externally on the load piston. The cell and back pressures were measured through two sensors connected to the cell volume or the drainage lines of the sample, respectively. For the measurement of volume changes during the consolidation phase, a burette system was used. One burette is connected to the pore space of the sample, while the water level in the second burette used as reference is kept constant throughout the test. Both burettes are connected to a differential pressure transducer, which measures changes in the difference of the pressures and thus water levels in both burettes. Changes in the water level in the burette correspond to a volume change of the sample: An increase in the water level inside the burette

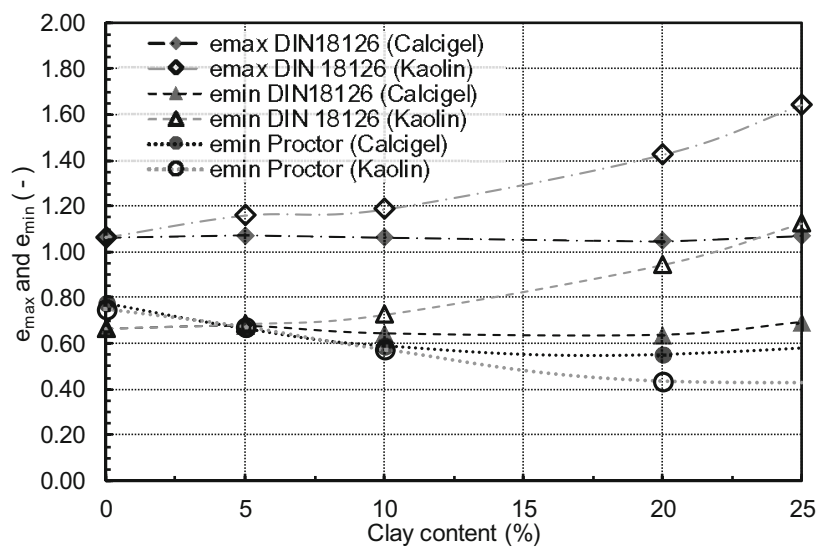

Fig. 2 Maximum and minimum void ratios of the sand-clay mixtures 
would imply compaction, while a decrease would signify dilatancy.

A latex membrane with thickness of $0.7 \mathrm{~mm}$ was used for the actual tests. Besides, the usage of large specimens and a granular host material with relatively small mean grain size minimized any effects of membrane penetration $[6,40]$ in the current experiments. A calculation according to Omar and Sadrekarimi [42] confirmed that the effects of membrane penetration and membrane resistance are negligible. Thus, they were not taken into consideration in the analysis of the tests. The end-bearing friction was further minimized using rigid stainless steel platens covered by a thin layer of grease and a rubber membrane (smeared end plates) and was therefore deemed to have a negligible influence on the experimental results $[42,60]$.

\subsection{Sample preparation}

Triaxial samples were prepared using the moist tamping (MT) method. The main advantage of MT over air pluviation (AP) is that particle segregation during sample preparation is minimized ensuring a homogenous gradation throughout. Furthermore, obtaining both loose and dense specimens of mixtures with predefined target densities is comparatively easier through MT.

The triaxial samples measured $10 \mathrm{~cm}$ in diameter and $20 \mathrm{~cm}$ in height. For sample preparation, a mold lined with the latex membrane was mounted on the pedestal of the triaxial cell. The prepared material of a certain mixture was placed in the mold in eight layers of $2.5 \mathrm{~cm}$ thickness each. After weighting the material for each layer, it was filled into the mold, distributed evenly over the cross-sectional area and compacted to the desired density using a plastic tamper. To check the layer thickness, the distance from the upper edge of the mold to the layer surface was measured. This procedure was repeated for each layer until all eight layers were placed.

\subsection{Test procedure}

After sample preparation, the triaxial cell was assembled and filled with water. The vacuum used for sample stabilization during the preparation process was replaced by a small cell pressure. $\mathrm{CO}_{2}$ was slowly circulated through the sample from bottom to top. After that, saturation with deaired water followed until no more air bubbles emerged at the outlet of the drainage lines. After water saturation, the drainage lines were connected to the burette system used for volume change measurements. The cell and back pressures were raised simultaneously to 240 and $200 \mathrm{kPa}$, respectively. The sample was kept overnight under these pressures to improve saturation. A sufficient degree of saturation was checked by means of the $B$-value test. $B$ - values larger than 0.95 were achieved for all tested specimens (see Table 2). The cell pressure and the external vertical force were then increased to the desired isotropic effective stress level $\left(p_{0}{ }^{\prime}=100\right.$ or $200 \mathrm{kPa}$, a single test was performed under $250 \mathrm{kPa}$ ) keeping the back pressure constant at $200 \mathrm{kPa}$.

While the volume changes could be directly measured during the consolidation phase, only the vertical deformation was recorded during the phases of saturation and back pressure application, which is inevitable when measuring volume changes via the pore water. The volume change measurements can only start when the pore space is fully water-saturated. Furthermore, a compression of the pore water during back pressure application should not be mixed up with a volume change of the samples. It was assumed that the sample deformations during the saturation and back pressure application phases, which were rather small in the current study, occur only in the vertical direction. Thus, volume changes during these phases were calculated as the change of the height of the sample times its initial cross-sectional area. The sum of these volume changes and the much larger ones during consolidation were then used to calculate the initial (post-consolidation) dimensions, void ratios $e_{0}$ and relative densities $I_{\mathrm{D} 0}$ of the specimens given in Table 2. All tests were carried out in a consolidated and undrained configuration, and shearing was terminated at a vertical strain of at most $25 \%$ due to limitations of the displacement transducer (Fig. 3). The details of all performed static triaxial tests are provided in Table 2.

\section{Experimental results}

\subsection{Clean Hostun sand}

Figure 4 shows the undrained behavior of clean Hostun sand prepared with four different densities and consolidated at two different initial effective mean stresses of $p_{0}^{\prime}=100 \mathrm{kPa}$ and $200 \mathrm{kPa}$. From the curves of deviatoric stress $q$ versus vertical strain $\varepsilon_{1}$ in Fig. 4 a, it can be seen that for the same $p_{0}{ }^{\prime}=100 \mathrm{kPa}$, an increase in density $I_{\mathrm{D} 0}$ (or a decrease in void ratio, $e_{0}$ ) leads to larger deviatoric stresses $q$ at the same axial strain $\varepsilon_{1}$. The loosest specimen $\left(I_{\mathrm{D} 0}=0.133 / e_{0}=1.009, \quad p_{0}{ }^{\prime}=100 \mathrm{kPa}\right)$ shows a pronounced softening (decrease of $q$ ) after a comparably small strain $\left(\varepsilon_{1}<1 \%\right)$. The two denser samples tested at the same pressure show a strain hardening response, which becomes more distinct with increasing density. For the densest specimen $\left(I_{\mathrm{D} 0}=0.612 / e_{0}=0.819\right)$ tested at the higher pressure $p_{0}{ }^{\prime}=200 \mathrm{kPa}$, a steep increase in deviatoric stress till $\varepsilon_{1}=6.5 \%$ followed by almost constant $q$ values and a softening after $\varepsilon_{1}=15 \%$ is observed. This 


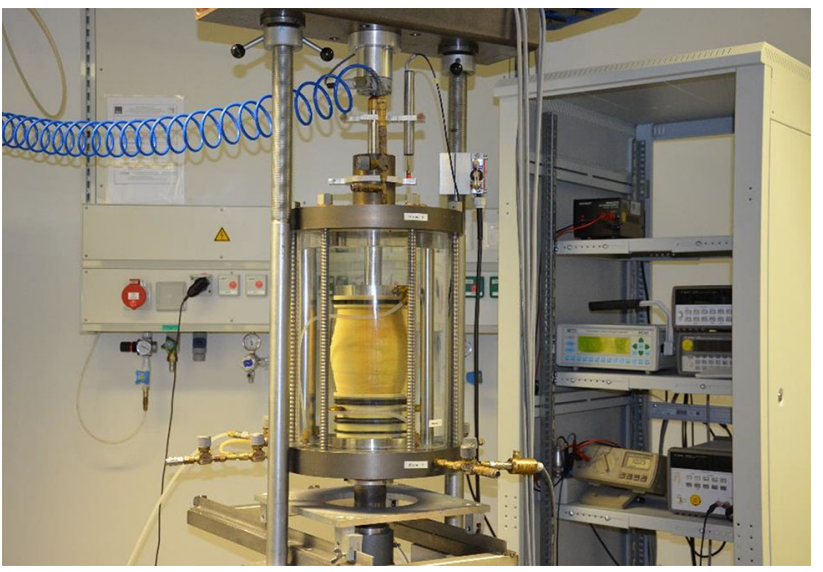

Fig. 3 Triaxial device applied for the current experiments

softening is caused by the formation of a shear band in the specimen which was not visible in the other three tests shown in Fig. 4.

The corresponding evolution of excess pore water pressure $\Delta u$ with increasing axial strain is shown in
Fig. 4b. The densest specimen shows a dilative tendency, i.e., a drop of pore water pressure, already after a relatively small strain of $\varepsilon_{1}=0.5 \%$. At axial strains larger than about $6 \%$, the pore water pressure does not change anymore in this sample. In contrast, the loosest specimen reveals a contractive response (increase in pore water pressure) throughout the test, corresponding to an increase in pore water pressure, which finally stays constant from about $\varepsilon_{1}=15 \%$. The other two specimens with densities in between show a gradual transition between the two extreme cases.

The effective stress paths in a $q-\not{ }^{\prime}$ diagram are shown in Fig. 4c. A unique slope of the curves in the final phase of the four tests is evident. The small kink at the end of the $q-$ $p$ c curve in the test on the densest sample is due to the shear band formation mentioned previously.

The effective mean stress $p^{\prime}$ at the largest vertical strain applied in the test, which is approximately corresponding to the steady or critical state $\left(p^{\prime}{ }_{\text {SS }}\right)$, is shown as a function of the initial (post-consolidation) void ratio in Fig. $4 \mathrm{~d}$ (a)

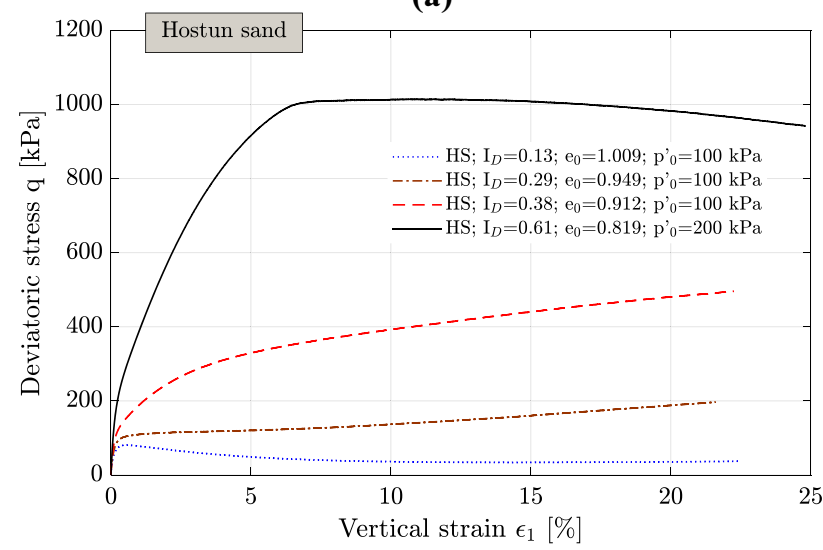

(c)

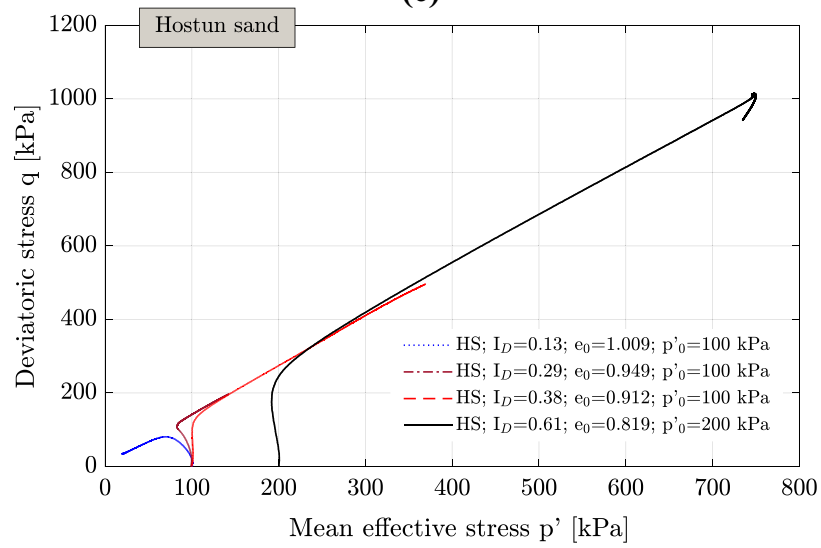

(b)

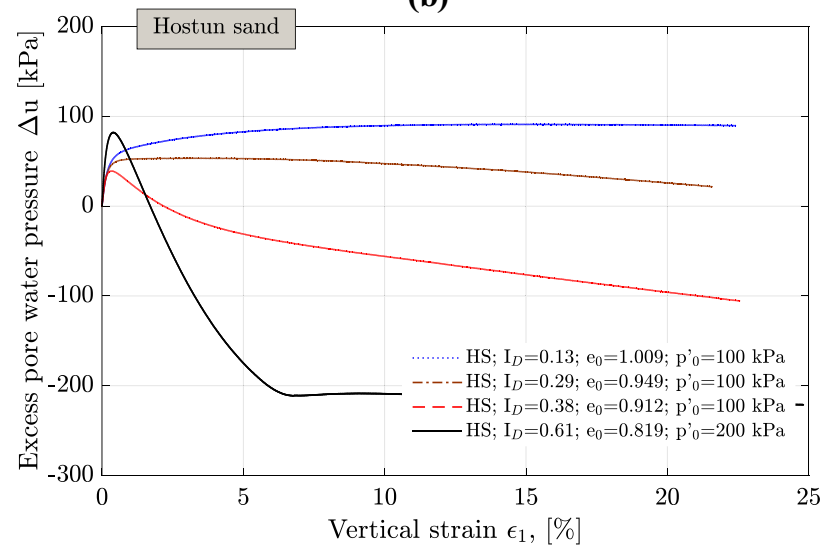

(d)

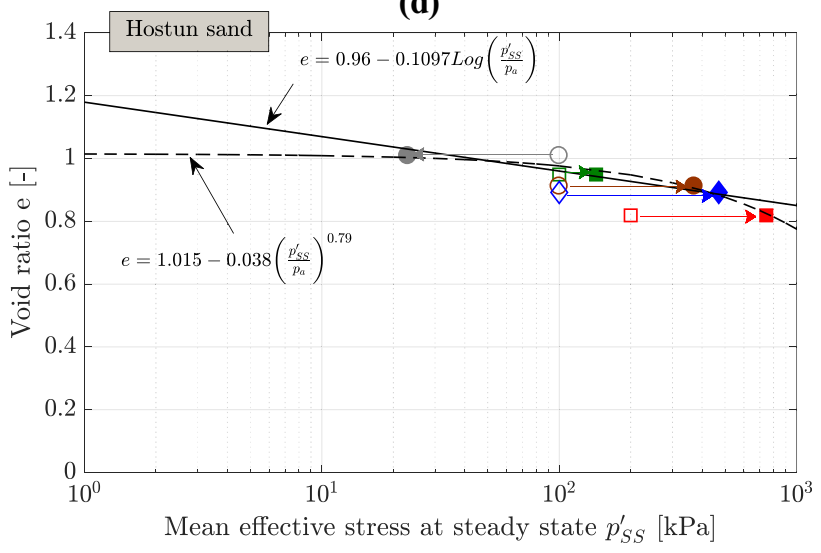

Fig. 4 Undrained monotonic behavior of clean Hostun sand, HS, with different densities: a deviatoric stress $q$ versus vertical strain $\varepsilon_{1}$; b excess pore water pressure, $\Delta u$, versus vertical strain $\varepsilon_{1} ; \mathbf{c}$ deviatoric stress $q$ versus mean effective stress $p^{\prime}$; and $\mathbf{d}$ post-consolidation void ratio $e$ versus mean effective stress at steady state (open symbols indicate initial states, and filled symbols indicate steady states) 
(filled symbols). The initial states at $p_{0}{ }^{\prime}=100$ or $200 \mathrm{kPa}$ have been added to the diagram (empty symbols). The steady-state data have been fitted by the two popular equations for the steady-state lines (SSLs) of Schofield and Wroth [57], Eq. (2), and Li and Wang [35], Eq. (3):

$e_{s s}=e_{\Gamma}-\lambda_{c}\left(\frac{p_{s s}^{\prime}}{p_{a}}\right)^{\xi}$

$e_{s s}=\Gamma-\lambda \cdot \log \left(\frac{p_{s s}^{\prime}}{p_{a}}\right)$

where $\mathrm{e}_{\mathrm{SS}}(-)$ and $\mathrm{p}_{\mathrm{SS}}(\mathrm{kPa})$ are the void ratio and the mean effective stress at steady state, respectively. Furthermore, $p_{\mathrm{a}}(\mathrm{kPa})$ is the atmospheric pressure $(100 \mathrm{kPa})$ and $e_{\Gamma}, \lambda_{c}$ and $\xi$ as well as $\Gamma$ and $\lambda$ are curve-fitting parameters. Equations (2) and (3) with the best-fit parameters obtained from curve fitting are added in Fig. 4d.

\subsection{Sand-kaolin mixtures}

Figure $5 \mathrm{a}-\mathrm{c}$ shows the test results for the mixtures of Hostun sand with $10 \%$ kaolin content. From the curves of deviatoric stress $q$ versus axial strain $\varepsilon_{1}$ in Fig. 5a, it is evident that an increase in the relative density causes an increase in the deviatoric stress $q$ at similar $\varepsilon_{1}$. The loosest tested specimen $\left(I_{\mathrm{D} 0}=0.65\right)$ shows significant strain softening, while strain hardening is observed for the two higher densities $\left(I_{\mathrm{D} 0}=0.72\right.$ and 0.80$)$. In Fig. 5b, the corresponding variation of the excess pore water pressure with axial strain is shown. The response of the loosest specimen is purely contractive, with an almost constant pore pressure after $10 \%$ axial strain, while the densest specimen shows a phase transformation toward a dilative tendency at relatively small strains. The response of the specimen with intermediate density is in between. The effective stress paths of the mixtures of sand with $10 \%$ kaolin for the different void ratios $e_{0}$ and initial mean effective stresses $p_{0}{ }^{\prime}=100$ and $200 \mathrm{kPa}$ are shown in Fig. 5c. The final effective stress states approximately lie on a unique line.

The test data for the mixtures with $20 \%$ kaolin content are provided in Fig. 5d-f. The stress strain curves in Fig. 5d show a pronounced strain softening for the samples with $I_{\mathrm{D} 0}=0.80$ and 0.81 , while strain hardening was observed at a similar density in the mixtures with $10 \%$ kaolin. Therefore, at comparable $I_{\mathrm{D}}$ values, an increase in the kaolin content from 10 to $20 \%$ results in a change from a strain hardening to a strain softening behavior, and consequently also to a reduction of deviatoric stress $q$ at a certain $\varepsilon_{1}$. The material response of the samples with $I_{\mathrm{D}-}$ $=0.80$ and 0.81 is purely contractive, which can be concluded from the curves of excess pore water pressure versus axial strain in Fig. 5e, which show an initial increase and almost constant values after $\varepsilon_{1}=7 \%$. In contrast, the sample with the highest tested $\mathrm{I}_{\mathrm{D} 0}$ shows a strain hardening response and a dilative tendency at $\varepsilon_{1}>1 \%$. The effective stress paths in Fig. 5f show again a quite unique failure line. The steady-state data for the two mixtures are shown in Fig. 6a and $b$ along with the equations describing the steady-state line and its best-fit parameters.

The curves of deviatoric stress and excess pore water pressure versus vertical strain for pure Hostun sand $\left(I_{\mathrm{D} 0}\right.$ $=0.61)$ and sand specimens with $10 \%$ kaolin $\left(I_{\mathrm{D} 0}=0.72\right)$ and $20 \%$ kaolin $\left(I_{\mathrm{D} 0}=0.81\right)$ are compared in Fig. 7a and b. All samples have been consolidated at $p_{0}{ }^{\prime}=200 \mathrm{kPa}$. Despite different densities, a clear trend can be deduced: With increasing clay content, an increasingly contractive behavior is observed, and consequently, lower shear stresses are mobilized at the same vertical strain. The specimen with a kaolin content of $20 \%$ and $I_{\mathrm{D} 0}=0.81$ behaves similar to a very loose sample of clean sand. The $q-\varepsilon_{1}$ curve of this sample shows a peak at a low strain value, followed by a pronounced softening until the steadystate value is reached at large strains. Simultaneously, the excess pore pressure, $\Delta u$, increases gradually until the constant steady-state value is reached. The loosest sample in terms of $I_{\mathrm{D} 0}$ in Fig. 7 is the Hostun sand sample with $I_{\mathrm{D} 0}=0.61$. For that sample, the deviatoric stress $q$ rises steeply up to a value of $1000 \mathrm{kPa}$ at a strain of about $7 \%$, remains almost constant afterward and finally drops slightly. The change in excess pore water pressure reveals a pronounced dilative tendency after a small phase of contractive behavior. The mixture with $10 \%$ kaolin content shows an intermediate response, lying between the two cases discussed previously. The influence of the kaolin content on the volume change tendencies becomes also evident in the effective stress paths shown in Fig. 7c. While the dilative response of the clean Hostun sand leads to high $p^{\prime}$ and $q$ values in the steady state, very low effective stresses are reached by the specimen with $20 \%$ kaolin showing a contractive response. The slope $(M)$ of the failure and steady-state lines in the $q-p^{\prime}$ diagram does not change significantly by the addition of the clayey fines. The described trends would be even clearer if samples with equal density were compared.

\subsection{Sand-calcigel bentonite mixtures}

The test results for the mixtures with $10 \%$ calcigel bentonite are presented in Fig. 8a-c. The curves of deviatoric stress versus vertical strain for $p^{\prime}{ }_{0}=200 \mathrm{kPa}$ in Fig. 8a show again, as expected, higher deviatoric stresses at a certain vertical strain with increasing density. The specimen with the largest tested density $I_{\mathrm{D} 0}=0.61$ shows a continuous strain hardening tendency, while the other two specimens with lower $I_{\mathrm{D} 0}\left(I_{\mathrm{D} 0}=0.43\right.$ and 0.55$)$ undergo 
(a)

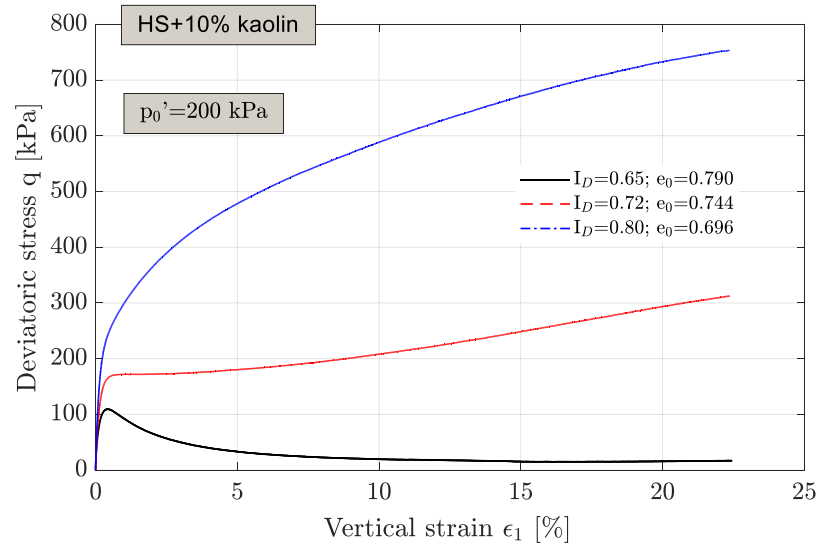

(c)

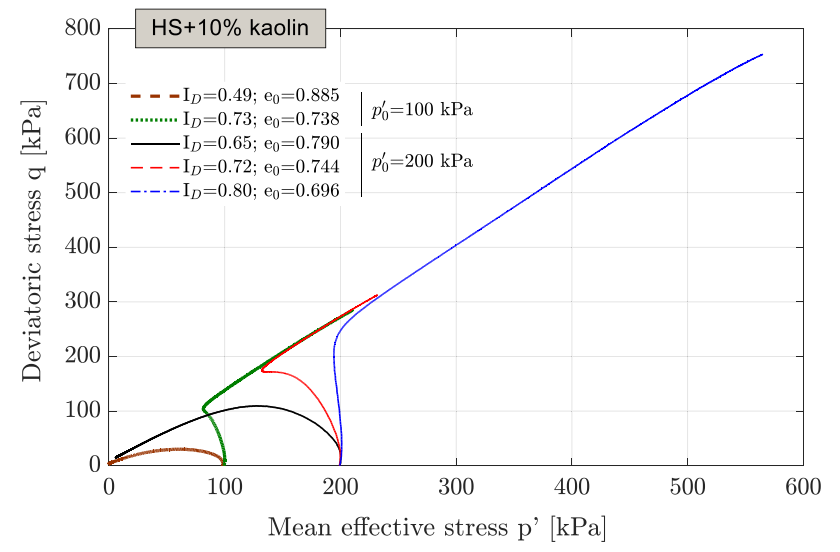

(e)

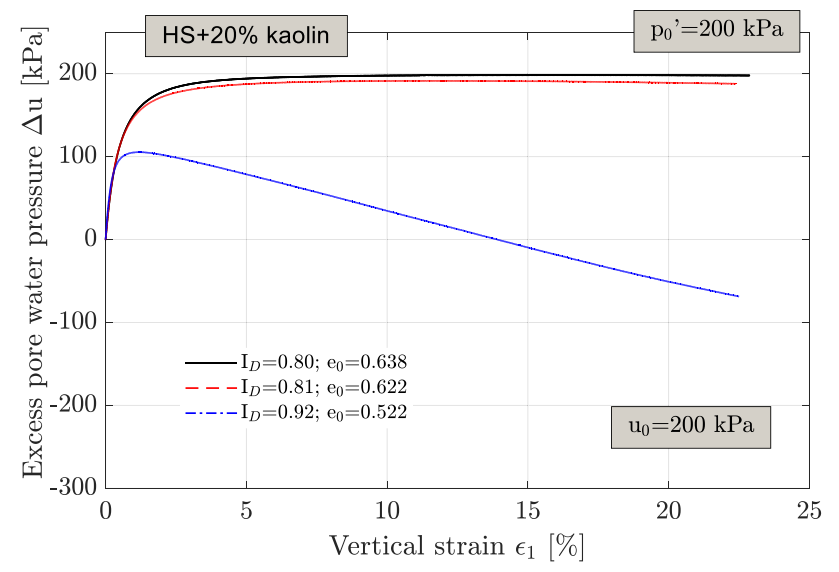

(b)

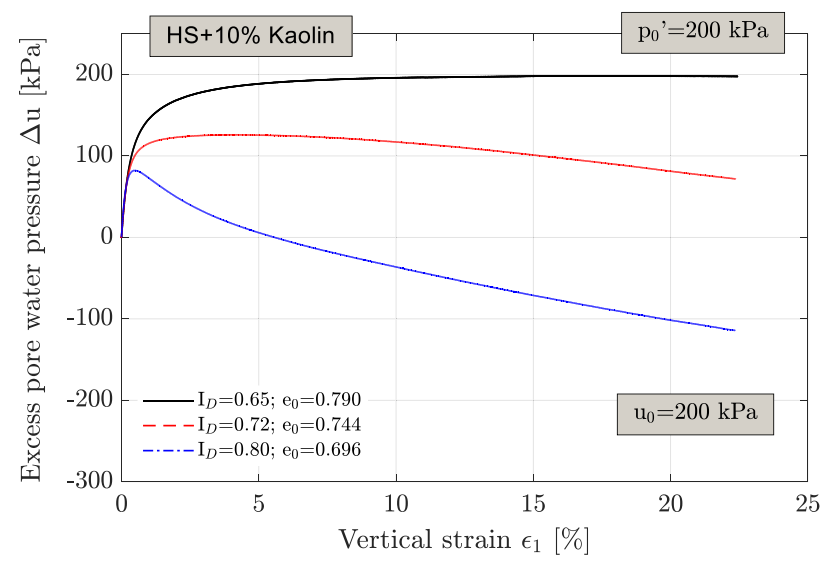

(d)

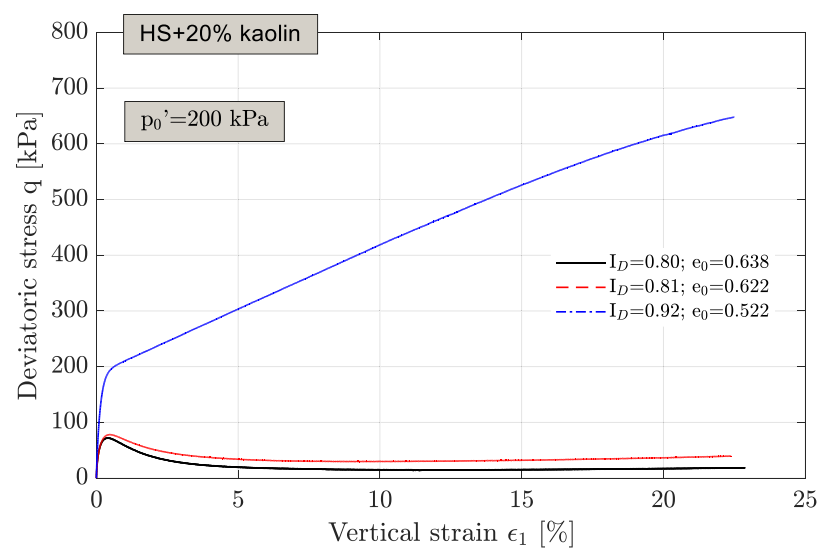

(f)

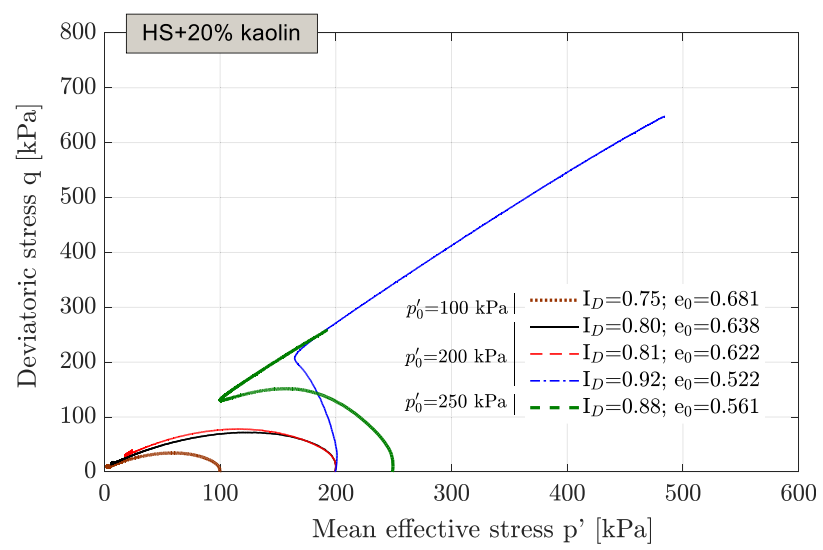

Fig. 5 Undrained monotonic behavior of Hostun sand with $10 \%$ kaolin: a deviatoric stress $q$ versus vertical strain $\varepsilon_{1}$, b excess pore water pressure $\Delta u$ versus vertical strain $\varepsilon_{1}, \mathbf{c}$ deviatoric stress $q$ versus mean effective stress $p^{\prime}$; undrained monotonic behavior of Hostun sand with $20 \%$ kaolin: $\mathbf{d}$ deviatoric stress $q$ versus vertical strain $\varepsilon_{1}$, e excess pore water pressure $\Delta u$ versus vertical strain $\varepsilon_{1}$ and $\mathbf{f}$ deviatoric stress $q$ versus mean effective stress $p^{\prime}$

strain softening. The response of the sample with the lowest tested $I_{\mathrm{D} 0}$ is purely contractive, while either a very small $\left(I_{\mathrm{D} 0}=0.55\right)$ or a pronounced dilatancy $\left(I_{\mathrm{D} 0}=0.61\right)$ after phase transformation is observed for the two higher densities (Fig. 8b). The effective stress paths for the various densities and initial stresses are shown in Fig. 8c, again with a good agreement of the inclinations in the final test phase. 
(a)

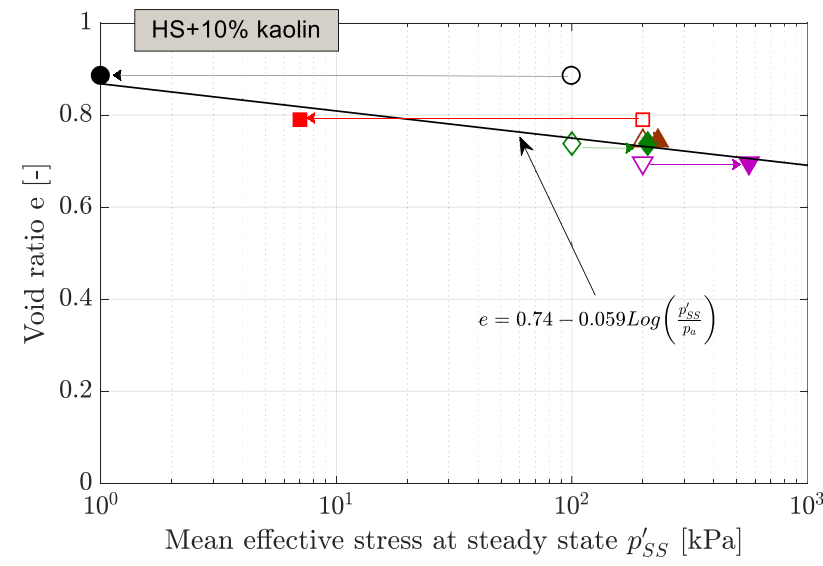

(b)

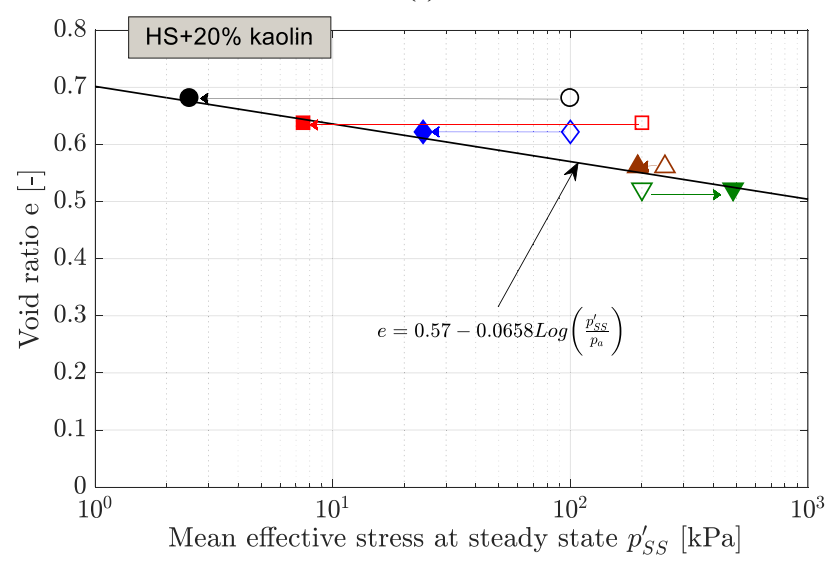

Fig. 6 Steady-state lines for the samples of Hostun sand with a 10\% and b $20 \%$ kaolin, respectively (empty symbols = initial states, filled symbols $=$ steady states)

Figure 8e-f provides the measured data for the mixtures with $20 \%$ calcigel bentonite. For the densest specimen $\left(I_{\mathrm{D} 0}=0.83\right)$, a local peak of the $q$ versus $\varepsilon_{1}$ relationship in Fig. 8e is observed around $0.5 \%$ vertical strain, followed by a slight decrease till $\varepsilon_{1}=2 \%$ and a subsequent continuous strain hardening. For the specimen with $I_{\mathrm{D}}=0.69$, the course of $q$ versus $\varepsilon_{1}$ is similar, with a strain hardening tendency noted after $\varepsilon_{1}=7 \%$, although not as prominent as in the previous case. The third specimen with the lowest tested density $\left(I_{\mathrm{D} 0}=0.57\right)$ exhibits continuous strain softening with a constant value of deviatoric stress reached at $\varepsilon_{1}$ of around $7 \%$. The variation of the excess pore pressure with $\varepsilon_{1}$ in Fig. 8e reveals that the response is predominantly contractive for all three tested samples. A slight dilative tendency is observed for the samples with $I_{\mathrm{D} 0}$ $=0.69$ and 0.83 which becomes somewhat more pronounced with increasing density. The corresponding effective stress paths are shown in Fig. 8f. The considerable reduction of $p^{\prime}$ up to the steady or phase (a)

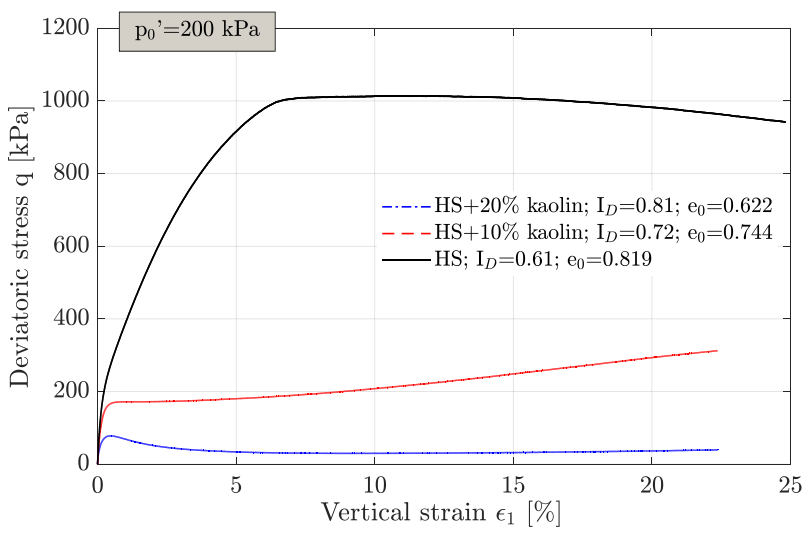

(b)

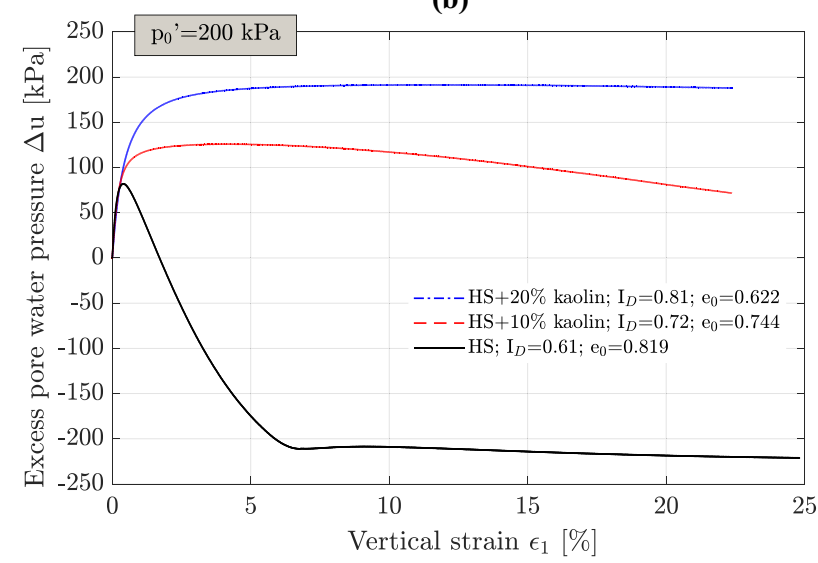

(c)

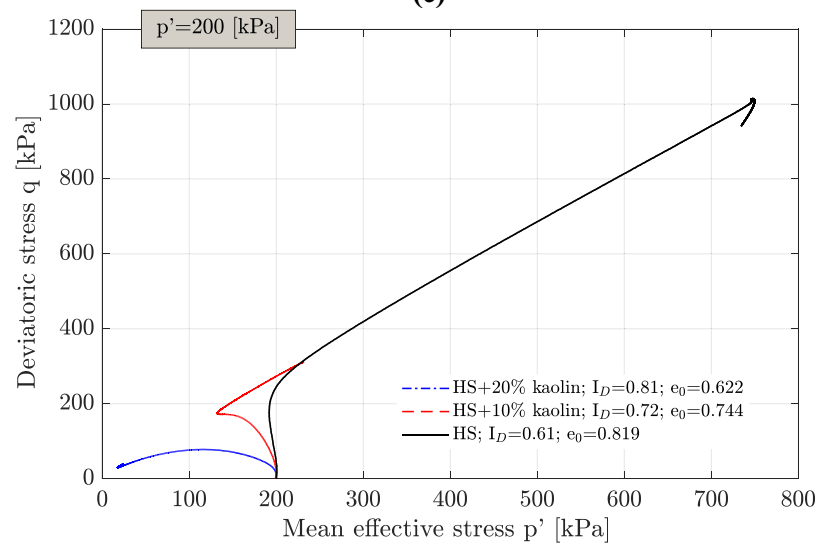

Fig. 7 Effect of kaolin content on the relationships: a $q-\varepsilon_{1} ; \mathbf{b} \Delta u-\varepsilon_{1}$; and $\mathbf{c} q-p^{\prime}$ for samples consolidated at mean effective stress $p_{0}{ }^{\prime}=200 \mathrm{kPa}$

transformation states reflects the predominant contractive response of the samples.

Figure 9 shows the steady-state data for the two sandcalcigel mixtures, together with the equations describing the steady-state line. It is interesting to note that the first term in the steady-state equations (value of SSL at $p^{\prime}=p_{\mathrm{a}}$ ) is smaller for $20 \%$ than for $10 \%$ calcigel content, while the 
(a)

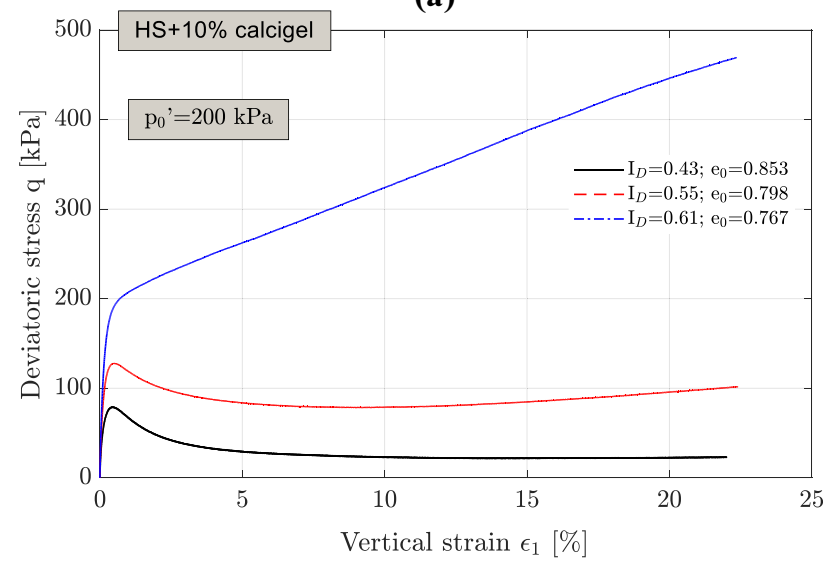

(c)

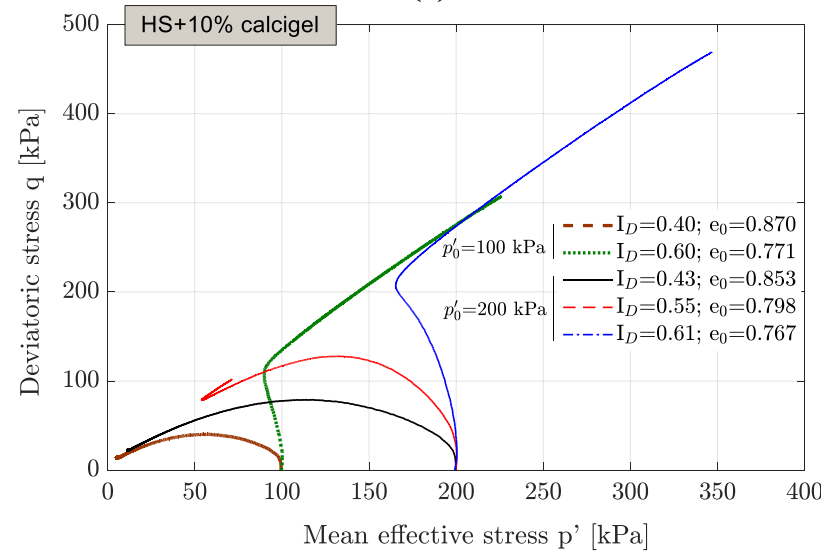

(e)

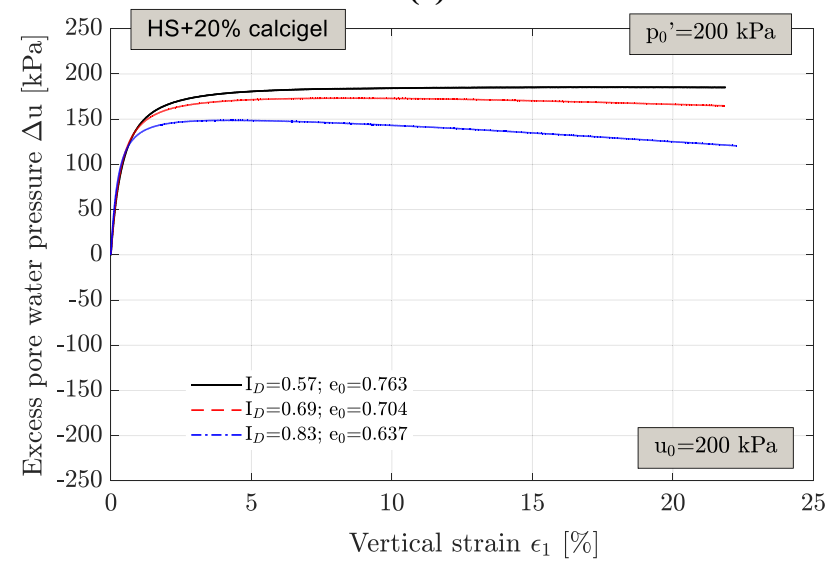

(b)

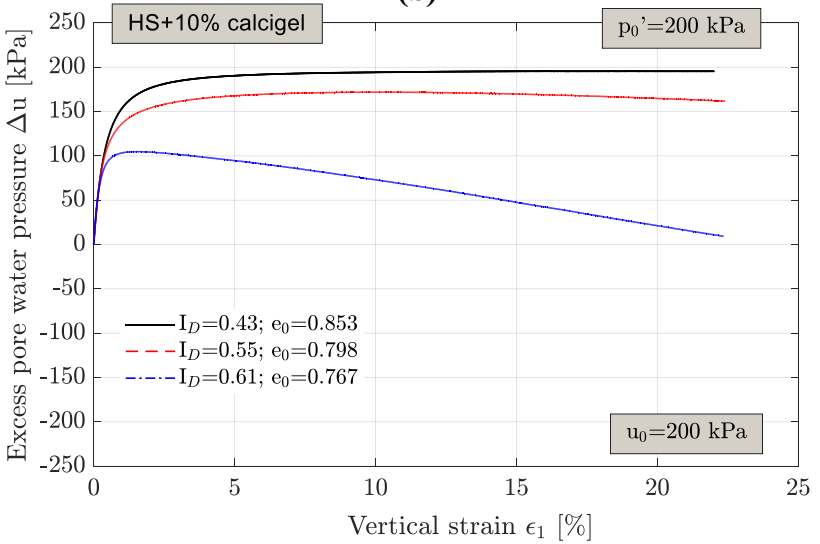

(d)

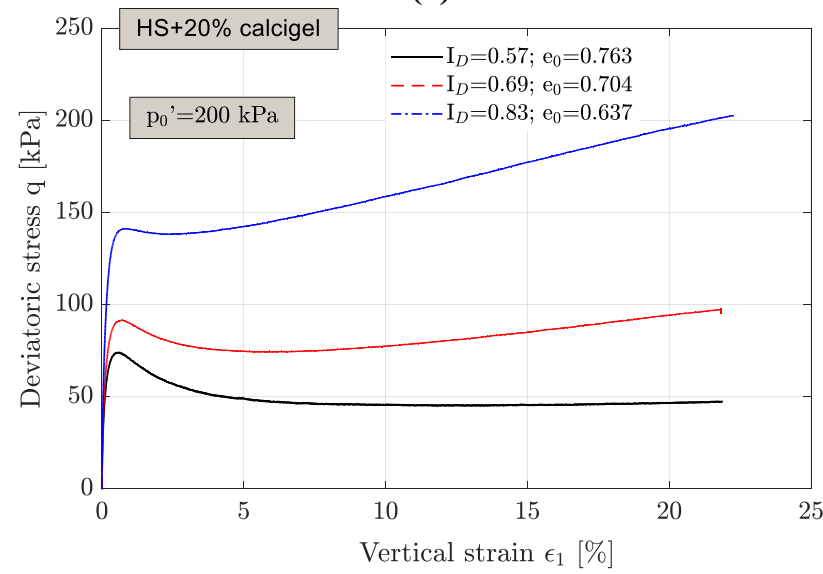

(f)

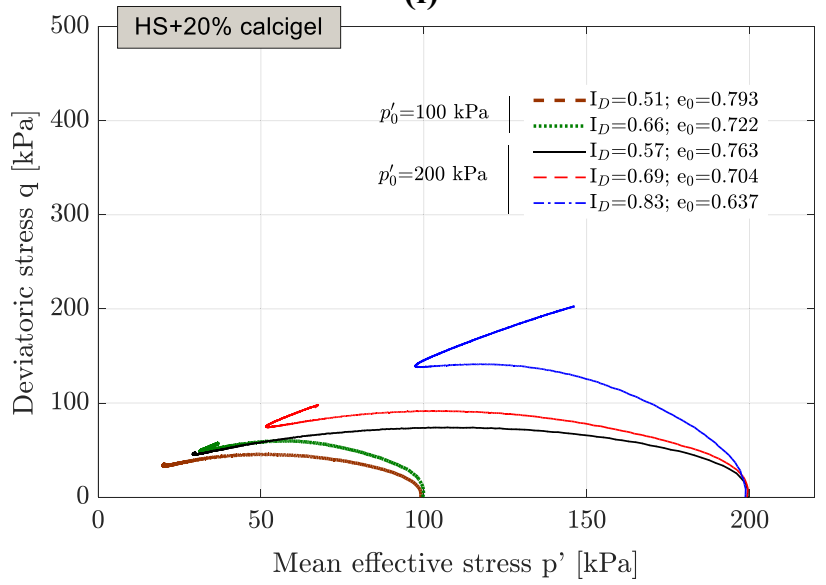

Fig. 8 Undrained monotonic behavior of Hostun sand with $10 \%$ calcigel bentonite: a deviatoric stress $q$ versus vertical strain $\varepsilon_{1}$, b excess pore water pressure $\Delta \mathrm{u}$ versus vertical strain $\varepsilon_{1}$, c deviatoric stress $q$ versus mean effective stress $p^{\prime}$; undrained monotonic behavior of Hostun sand with $20 \%$ calcigel bentonite: d deviatoric stress $q$ versus vertical strain $\varepsilon_{1}$, e excess pore water pressure $\Delta u$ versus vertical strain $\varepsilon_{1}$ and f deviatoric stress $q$ versus mean effective stress $p^{\prime}$

inclination of the SSL (pre-factor of the logarithm) is considerably larger. This may indicate that the threshold calcigel content lies between 10 and $20 \%$.

The diagrams in Fig. 10a and $\mathrm{b}$ show the variation of deviatoric stress and the change in pore water pressure against $\varepsilon_{1}$ for the clean sand sample as well as the mixtures with $10 \%$ and $20 \%$ calcigel content. The three specimens compared in that figure have approximately the same relative density $\left(0.57<I_{\mathrm{D} 0}<0.61\right)$. Evidently, the $q-\varepsilon_{1}$ and $\Delta u-\varepsilon_{1}$ curves differ significantly, and a similar trend as in 
(a)

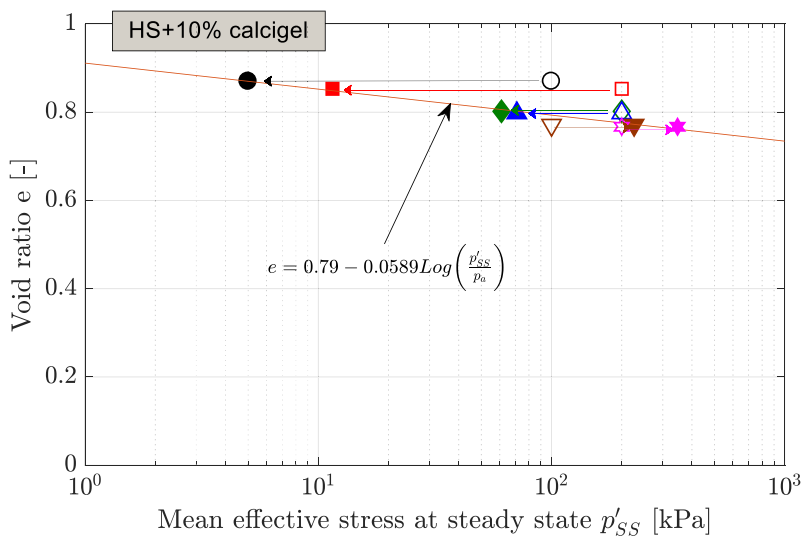

(b)

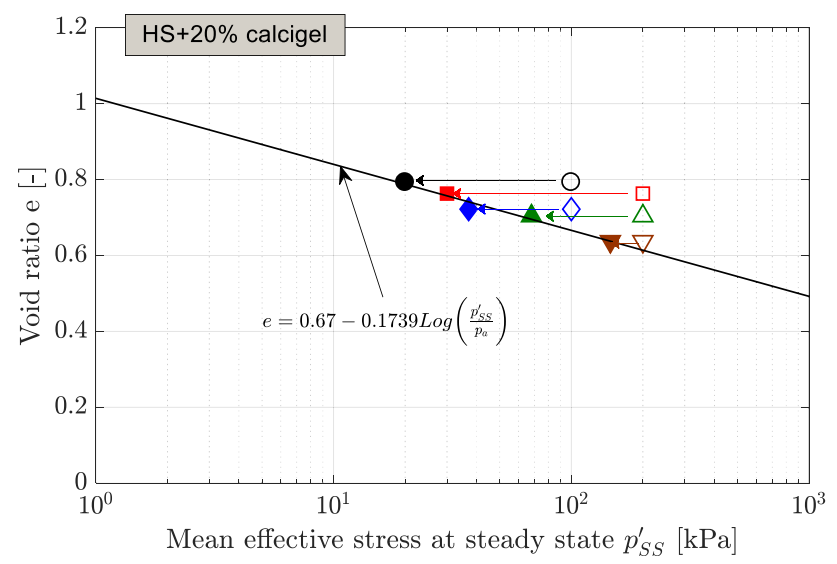

Fig. 9 Steady-state lines for the samples of Hostun sand with a $10 \%$ calcigel and b $20 \%$ calcigel, respectively

case of the sand-kaolin mixtures can be observed, where with increasing clay content, an increasingly contractive behavior accompanied by a tendency to strain softening is noted. For the specimen with $20 \%$ calcigel, the maximum $q$ (around $80 \mathrm{kPa}$ ) is already mobilized at low strains ( $\sim 1 \%$ ), and with increasing strain, $q$ drops slightly until it remains constant at about 7\% vertical strain. Simultaneously, the pore water pressure increases by about $180 \mathrm{kPa}$ within a strain of $7 \%$ after which it remains constant, signifying a purely contractive behavior up to the steady state. For the $10 \%$ calcigel sample, a higher $q$ (nearly $200 \mathrm{kPa}$ ) is mobilized compared to the $20 \%$ calcigel sample at low $\varepsilon_{1}(\sim 1 \%)$, followed by a continuous increase of $q$ over the entire strain range. The pore water pressure increases up to about $2 \%$ vertical strain followed by a decreasing trend up to the end of the test. The highest deviatoric stress is mobilized in the test on the pure Hostun sand where $q$ increases to $1000 \mathrm{kPa}$, accompanied by a significant decrease in the pore water pressure after a short contractive initial phase. Besides, also in the case of the (a)

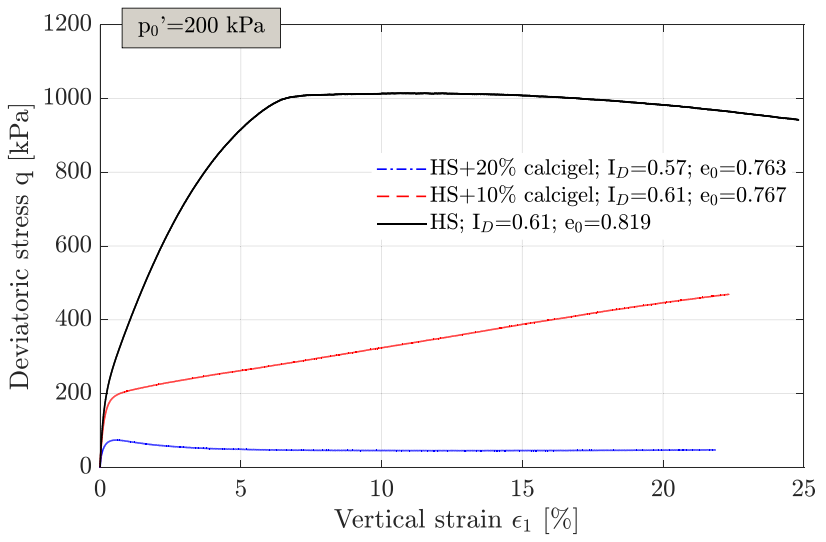

(b)

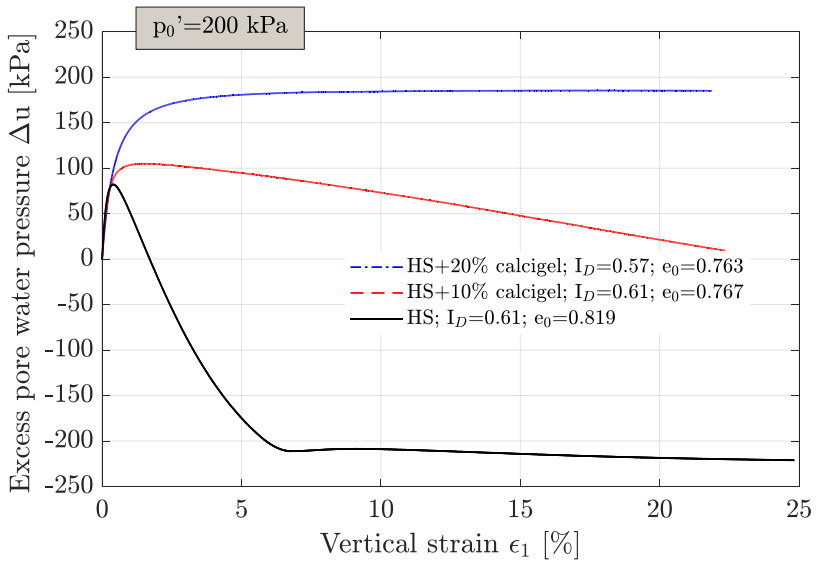

(c)

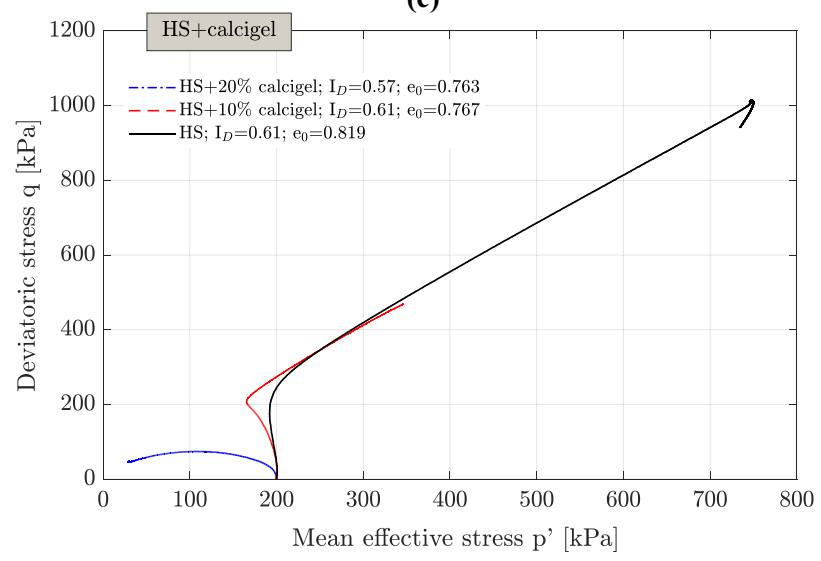

Fig. 10 Effect of calcigel bentonite content on the relationships a $q-$ $\varepsilon_{1}$, b $\Delta u-\varepsilon_{1}$ and $\mathbf{c} q-p^{\prime}$ curves for samples consolidated at an initial mean effective stress $p_{0}^{\prime}=200 \mathrm{kPa}$

sand-calcigel mixtures, the addition of clay does not have a significant effect on the slope of the SSL in the $q-p^{\prime}$ diagram (Fig. 10c), similar to the case of the sand-kaolin mixtures. 


\subsection{Influence of clay type}

As described above, the two clays used in this study differ substantially in terms of their plasticity. To assess the effect of clay type, samples containing different clays but with the same clay content and similar relative density are compared. Figure $11 \mathrm{a}, \mathrm{b}$ and c compiles the $q$ versus $\varepsilon_{1}$, $\Delta u$ versus $\varepsilon_{1}$ and $q$ versus $p^{\prime}$ curves measured for specimens containing either $10 \%$ kaolin $\left(I_{\mathrm{D} 0}=0.65\right)$ or $10 \%$ calcigel $\left(I_{\mathrm{D} 0}=0.61\right)$. Evidently, the specimen containing $10 \%$ kaolin shows a more contractive response than that with $10 \%$ calcigel (Fig. 11b), and the stress-strain response (strain softening vs. hardening) also differs strongly (Fig. 11a). In the test on the specimen containing 10\% kaolin, the maximum deviatoric stress of about $100 \mathrm{kPa}$ is reached at a vertical strain of approx. $1 \%$, followed by a softening with a decrease of $q$ to $20 \mathrm{kPa}$ during further shearing. In the same test, the excess pore water pressure $\Delta \mathrm{u}$ increases by about $200 \mathrm{kPa}$ within the first $10 \%$ of vertical strain and remains almost constant with further straining. The specimen containing $10 \%$ calcigel shows a significantly stiffer behavior. Within the first $1 \%$ strain, $q$ increases to $200 \mathrm{kPa}$ and the pore water pressure grows by only $100 \mathrm{kPa}$, which is much less than in the case of $10 \%$ kaolin content. After phase transformation, a dilative response is observed, while $q$ continues to rise with a constant gradient.

The significantly different behavior despite the same clay content and comparable $I_{\mathrm{D} 0}$ becomes even clearer when looking at the effective stress paths in Fig. 11c. Starting from the same $p_{0}{ }^{\prime}=200 \mathrm{kPa}$, the mean effective stress drops to almost zero in case of the $10 \%$ kaolin sample, corresponding to the purely contractive response mentioned above. In contrast, in the case of the $10 \%$ calcigel sample, after a slight decrease of $p^{\prime}$ during the contractive initial phase, the mean effective stress increases during the following phase with dilative tendency, reaching $p^{\prime}=350 \mathrm{kPa}$ at the end of the test.

Also for $20 \%$ clay content, clear differences can be observed in the measured data for the two different types of clay (Fig. 11d-f). For similar relative density, the sandkaolin samples have a greater tendency to soften than the sand-calcigel mixtures. Figure 11d shows that at low strain $\left(\varepsilon_{1}=1 \%\right)$, the specimen containing $20 \%$ calcigel reaches a significantly higher local maximum of the deviatoric stress $\left(q_{\max }=145 \mathrm{kPa}\right)$ than the specimen containing 20\% kaolin $\left(q_{\max }=75 \mathrm{kPa}\right)$. Furthermore, $q$ drops only slightly after the peak in the specimen containing $20 \%$ calcigel and then rises again continuously. In contrast, $q$ drops to almost half of its maximum value in the test on the specimen containing $20 \%$ kaolin, before it increases slightly again at high strain levels $\left(\varepsilon_{1}>15 \%\right)$.
A less contractive behavior of the specimen containing $20 \%$ calcigel before the phase transformation and a more pronounced dilative tendency afterward can be concluded from the development of pore water pressure in Fig. 11e. The increase in pore water pressure is higher in the specimen containing $20 \%$ kaolin (by about $185 \mathrm{kPa}$ ) than in the specimen containing $20 \%$ calcigel (150 $\mathrm{kPa}$ in maximum). For $20 \%$ calcigel, the pore water pressure decreases slowly at strains above 5\%, while the specimen containing $20 \%$ kaolin shows almost constant values of pore water pressure at large strains.

The more contractive response of the sand-kaolin mixture is confirmed by the effective stress paths in Fig. 11f, where the mean effective stress temporarily drops to a value below $20 \mathrm{kPa}$ in the specimen containing $20 \%$ calcigel, before it slightly re-increases at larger strains. The path for $20 \%$ calcigel shows a typical phase-transformation response, reaching a local minimum of $p^{\prime}$ slightly below $100 \mathrm{kPa}$ and a final value of about $145 \mathrm{kPa}$ at large strains.

\section{Discussion of results}

\subsection{Steady-state line}

This section analyzes the effect of clay content and clay type on the steady-state line, SSL, in the $e-p^{\prime}$ and $q-p^{\prime}$ planes in more detail. As evident from the curves of deviatoric stress or excess pore water pressure versus vertical strain discussed in the previous sections, for the specimens with higher density, which showed a dilative behavior at large strain, a steady state was not fully achieved even at a strain of $25 \%$. In these cases, the last measured data before the end of the test were used as an approximate of the steady state. The combinations of void ratio and mean effective stress at steady state obtained for the pure sand and the different sand-clay mixtures, already shown in Figs. 4d, 6 and 9, are compiled in the $e-p^{\prime}$ plane in Fig. 12. Equation (3) was adopted to describe the SSL. A curve fitting leads to the linear curves shown in Fig. 12. The best-fit parameters $\Gamma$ and $\lambda$ determined using the Excel function "Excel-Solver" are summarized in Table 3.

The SSLs for the clean Hostun sand and the sand-kaolin mixtures with $10 \%$ and $20 \%$ clay content shown in Fig. 12a are parallel to each other at approximately equal distances. Figure $12 b$ shows the SSLs determined for the calcigel mixtures. As can be seen, the SSL for the specimens containing $10 \%$ calcigel has a slightly lower inclination than that for clean sand, while the SSL for $20 \%$ calcigel content is steeper. This inconsistent trend might be explained with a possible exceedance of the threshold fines content, $f_{\text {thre }}$, so that the clay controls the behavior of the mixture with $20 \%$ calcigel content. It is well known that 
(a)

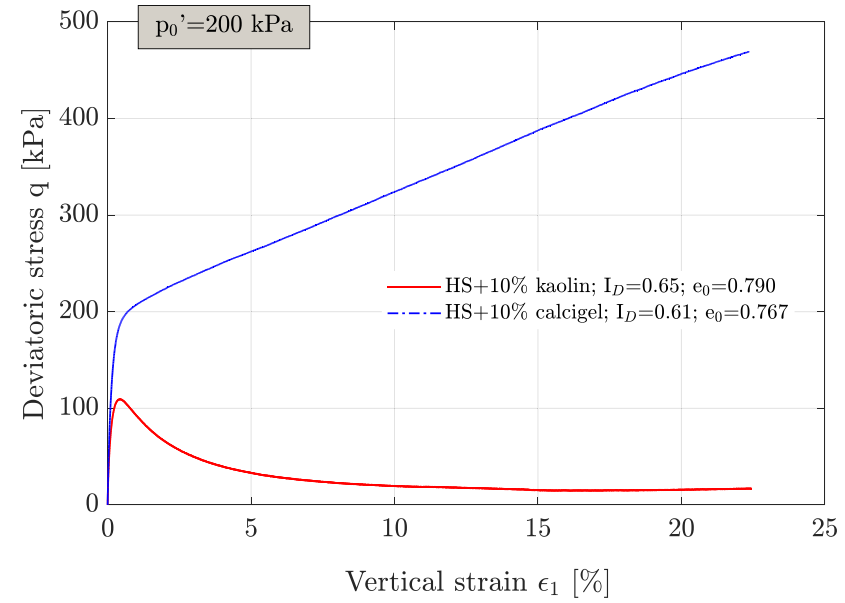

(c)

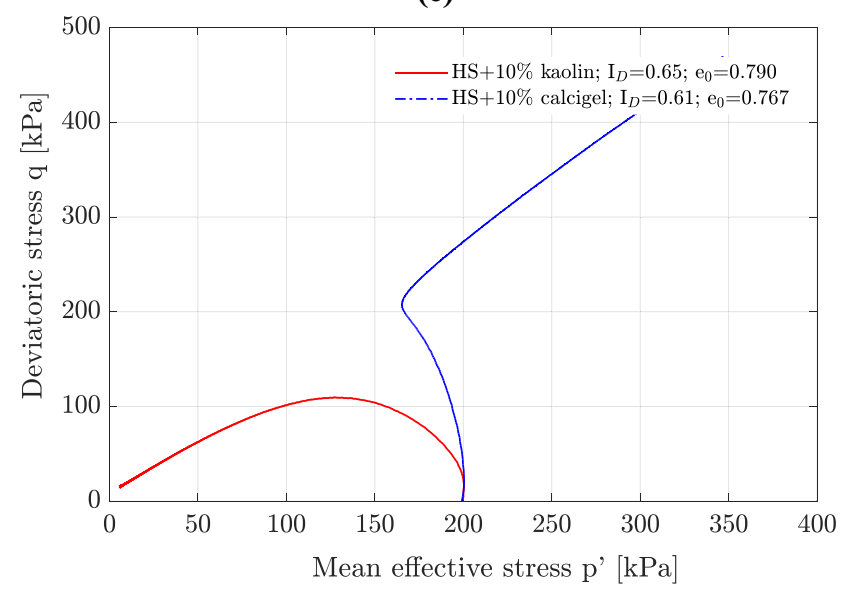

(e)

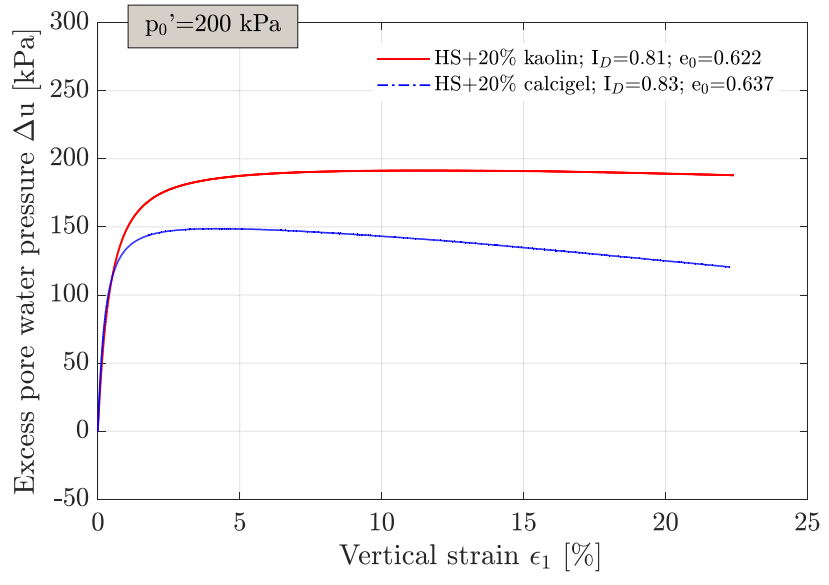

(b)

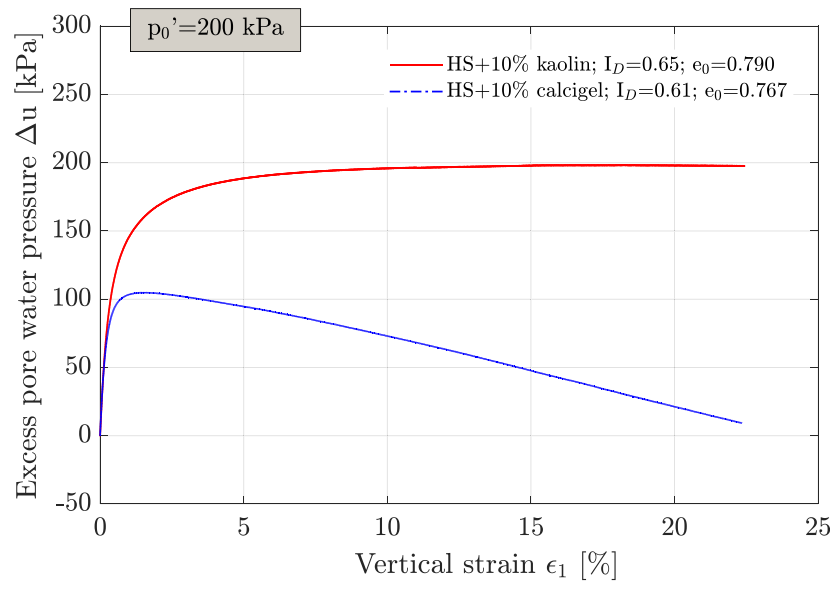

(d)

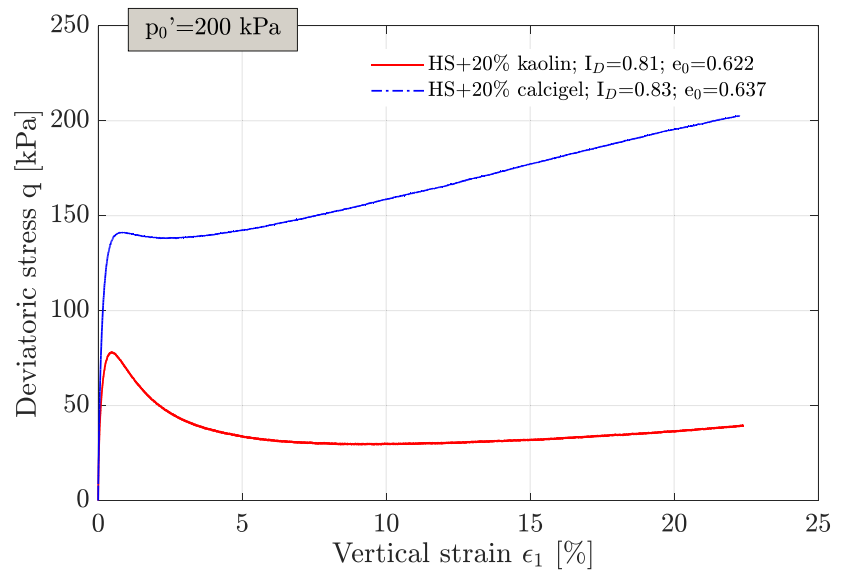

(f)

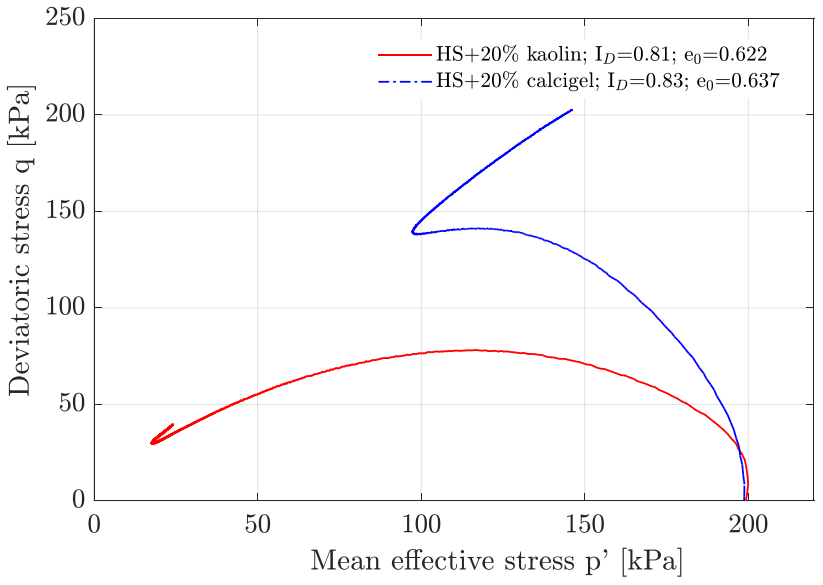

Fig. 11 Comparison of the relationships a $q$ versus $\varepsilon_{1}$, b $\Delta u$ versus $\varepsilon_{1}$ and $\mathbf{c} q$ versus $p^{\prime}$ for the samples containing $10 \%$ kaolin and calcigel, d $q$ versus $\varepsilon_{1}, \boldsymbol{e} \Delta \mathrm{u}$ versus $\varepsilon_{1}$ and $\mathbf{f} q$ versus $p^{\prime}$ for the samples containing $20 \%$ kaolin and calcigel

the inclination of the SSL in the $e-p^{\prime}$ diagram at $f_{\mathrm{c}}>f_{\text {thre }}$ differs from that at $f_{\mathrm{c}}<f_{\text {thre }}[62,70]$.
Figure 13 shows the effective stress state at the end of the undrained triaxial tests, which is identical to the steady state in most tests and used as an approximate for the 
(a)

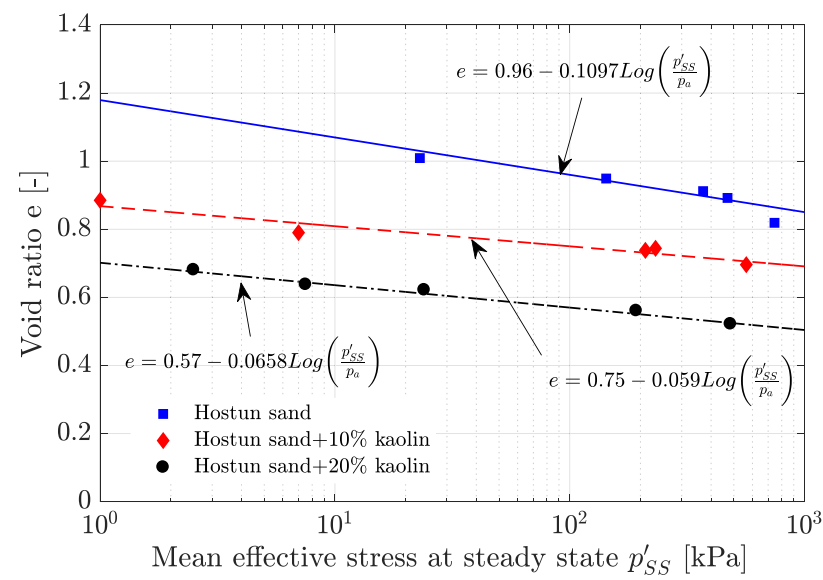

(b)

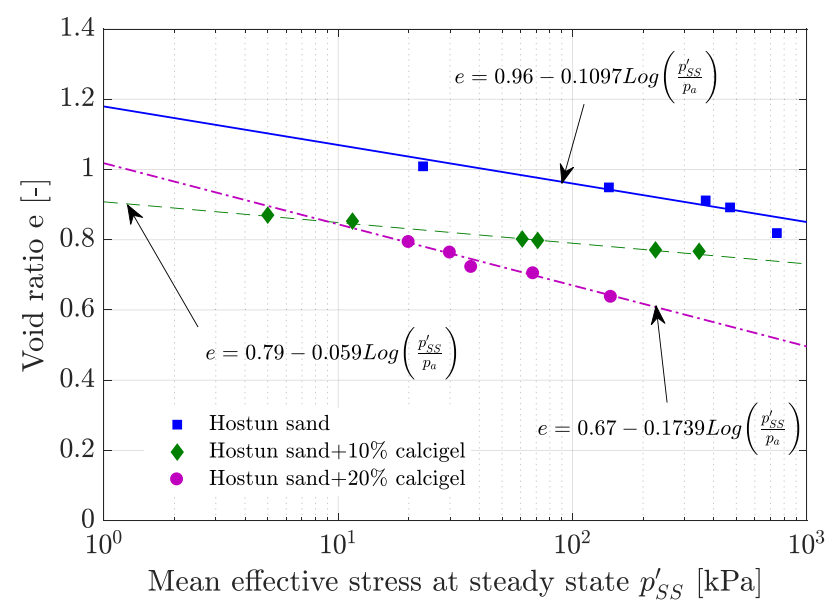

Fig. 12 Comparison of the steady-state lines of the Hostun sand with the a kaolin and $\mathbf{b}$ calcigel mixtures

steady state in the remaining tests, obtained for Hostun sand and the different sand-clay mixtures in a $q-p^{\prime}$ diagram. Evidently, the stress ratios $q / p^{\prime}$ at steady state observed for all mixtures are similar to the values of the host sand.

\subsection{Instability lines}

Samples of lower density subjected to undrained monotonic loading pass a local maximum in the deviatoric stress during the contractive phase, followed by a reduction of $q$ (strain softening) and (depending on density) a phase transformation, after which the mean effective stress and deviatoric stress increase again. The phase with a reduction of $q$ after the local maximum is also termed flow or partial flow liquefaction. The point in the $q-p^{\prime}$ plane at which the deviatoric stress takes its local maximum is denoted as the undrained instability point (UIS) (after [67]). The corresponding $q$ and $p^{\prime}$ values are denoted as $q_{\text {UIS }}$ and $p_{\text {UIS }}^{\prime}$ in the following. The line passing through the origin of the $q-$ $p^{\prime}$ plane and the UIS is defined as the flow liquefaction or instability line (after [7, 65, 67]), abbreviated as IL in the following. The instability line separates potentially unstable (above the IL) from stable (below the IL) stress states. It has been established by Lade and Pradel [31] that instability occurs when the stress ratio $\left(q / p^{\prime}\right)$ exceeds the instability line.

The UIS points for the various specimens of the mixtures of sand with $20 \%$ kaolin undergoing flow/partial flow are shown in Fig. 14a. For the Hostun sand and the different sand-clay mixtures, the instability points determined from the undrained tests on samples showing a strain softening response are collected in Fig. 14b, in a diagram giving the stress ratio $q_{\text {UIS }} / p^{\prime}$ UIS at UIS as a function of the initial void ratio $e_{0}$. Figure $14 \mathrm{~b}$ shows that the data of $q_{\mathrm{UIS}} /$ $p_{\text {UIS }}^{\prime}$ versus $e_{0}$ are shifted to the left-hand side with increasing fines content. Furthermore, it can be concluded that for the same void ratio, the ratio $q_{\mathrm{UIS}} / p_{\mathrm{UIS}}^{\prime}$ for sand containing $20 \%$ kaolin is lower than for the mixtures with $20 \%$ calcigel. This means that the specimens containing kaolin, i.e., a clay with lower $I_{\mathrm{P}}$, are more prone to instability and a flow / partial flow response than the mixtures with calcigel having a higher $I_{\mathrm{P}}$.

\subsection{Effect of clay content and clay type}

The bonding between successive layers in kaolinite is by both van der Waals forces and hydrogen bonds. The bonding is sufficiently strong ensuring that there is no interlayer swelling in the presence of water. In contrast, the bonding between successive layers in calcigel bentonite is by van der Waals forces and by cations that balance charge deficiencies in the structure. These bonds are weak and easily separated by cleavage or adsorption of water or other polar liquids.

Microscopic observations on sand-clay mixtures indicated that the clay particles tend to gather at the sand particle contact points, which can generate various forming

Table 3 Fitting parameters of Eq. (3) for the adopted mixtures

\begin{tabular}{llllll}
\hline Parameter & HS & HS $+10 \%$ Kaolin & HS $+20 \%$ Kaolin & HS $+10 \%$ Calcigel & HS $+20 \%$ Calcigel \\
\hline$\Gamma$ & 0.96 & 0.79 & 0.67 & 0.74 & 0.57 \\
$\lambda$ & 0.1097 & 0.0589 & 0.1739 & 0.0590 & 0.0658 \\
\hline
\end{tabular}


(a)

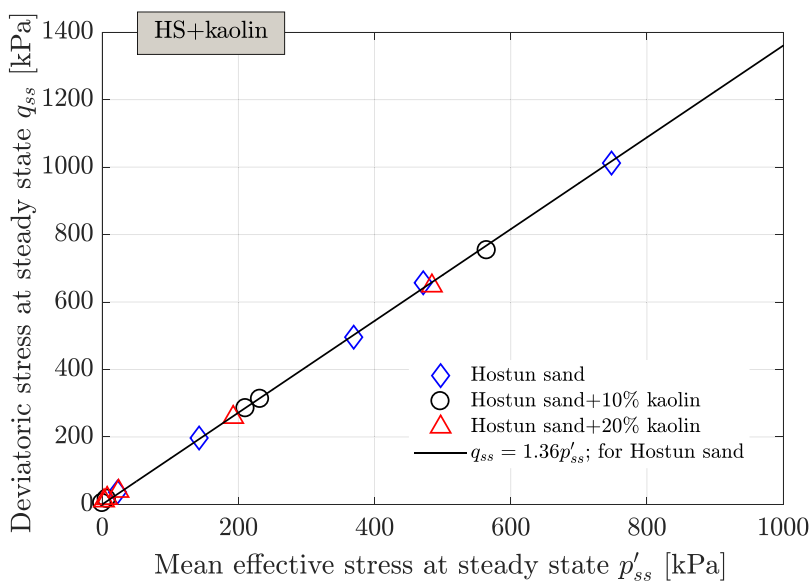

(b)

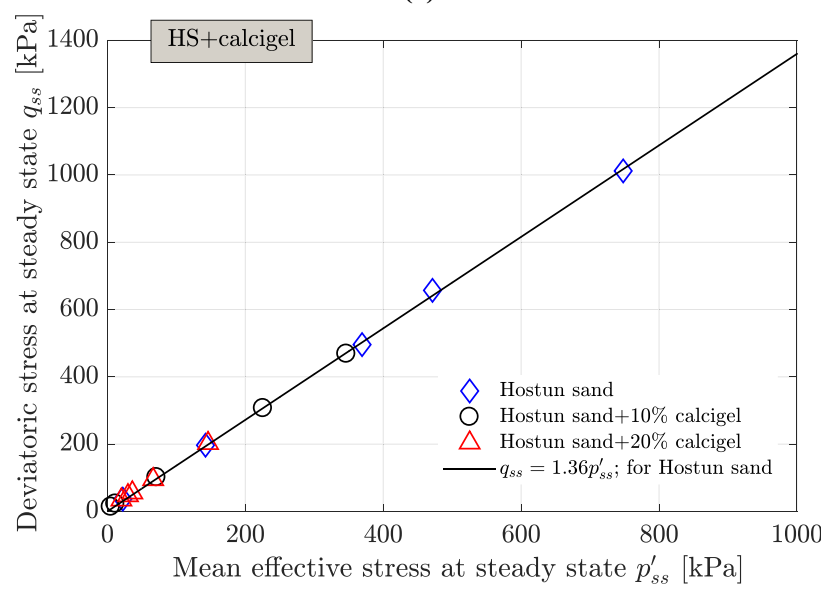

Fig. 13 Deviatoric stress $q_{\mathrm{SS}}$ versus mean effective stress $p_{\mathrm{SS}}^{\prime}$ at the end of the undrained triaxial tests (approximately steady state) for: a Hostun sand containing kaolin; b Hostun sand containing calcigel

features (e.g., [13]). Gratchev et al. [21] reported that soils containing plastic fines are susceptible to liquefaction due to the forming of an open micro-fabric, in which clay aggregations gathered at the sand particle contacts serve as low strength connectors. Adding more clay will increase the number of such low strength connections, which promotes the liquefaction susceptibility of the mixture. This is in agreement with the observed results in Figs. 6 and 10, where the mobilized deviatoric stresses decrease with increasing clay content, while simultaneously the volume change behavior is altered from dilative to contractive.

The different response observed for the two types of clay (Fig. 11) could be explained with differences in the bonding between the sand particles caused by the fines. Pusch and Yong [50] noted that kaolinite behaves as very fine silt soils consisting of quartz grains, and thereby, kaolinite has a lower specific surface area. As a result, the coating is more irregular and contains a greater amount of

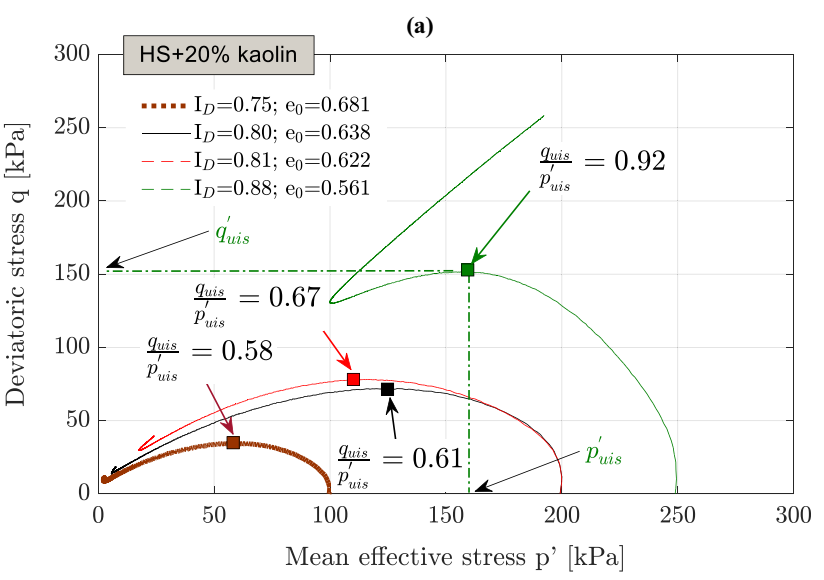

(b)

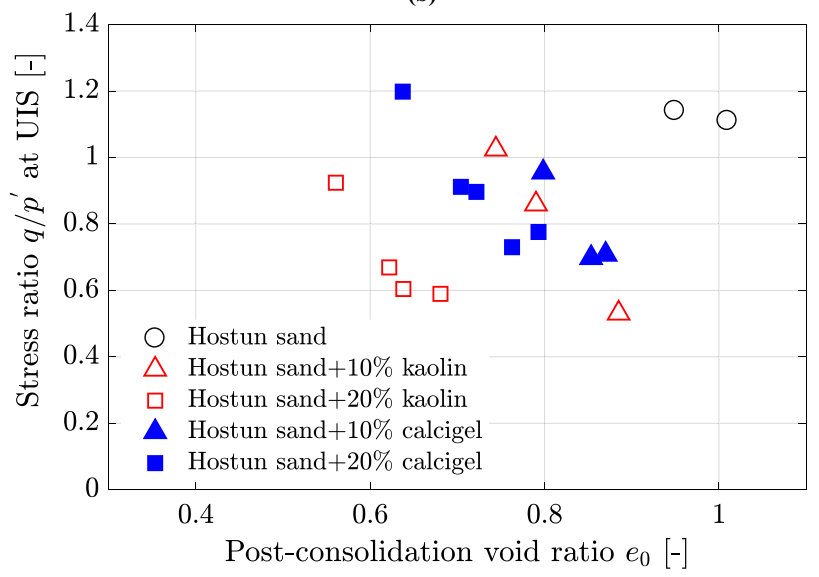

Fig. 14 a Instability points for the HS $+20 \%$ kaolin specimens in the $q-p^{\prime}$ plane, b instability points for Hostun sand and Hostun sand containing plastic fines in a $q / p^{\prime}-e_{0}$ diagram

large particles [22]. The kaolin particles gathered at the contact points between sand particles generate weak connections between particles, leading to an open micro-fabric that can easily collapse under loading. Therefore, the structure of sand-kaolin mixtures is susceptible to large volume changes (compaction) under drained conditions or a corresponding build-up of pore water pressure under undrained conditions, similar as observed for sand - silt mixtures (e.g., [32, 49, 52, 66-68], etc.).

In contrast, clay with a higher specific surface area and high plasticity index, as the calcigel bentonite in the current study, will produce a more smooth and regular coating around the sand grains [21, 50], probably leading to bondings with higher strengths compared to the kaolin (see also [9]). These adhesive bonds between the sand and clay particles are deemed to cause the observed less contractive behavior of the sand-calcigel mixtures accompanied by higher mobilized deviatoric stresses.

Another possible mechanism to describe the differences in Fig. 11 can be explained on the basis of the amount of 
free pore water. Because of strong bonding, kaolinite lamellae do not disperse into smaller units when water is added to the kaolinite soil, as during the saturation process. In contrast, when the calcigel-sand mixture is wetted, the weak bonding of the layers in calcigel permits further separation of the particles into extremely small flakes [22]. The adsorbed water has different physical properties and is more viscous in comparison with the free pore water $[1,22,50]$. The adsorbed water will be more strongly held and less mobile [9]. Under fully saturated conditions, larger quantities of free pore water are expected to be present in soils with kaolinite as the clay mineral than in soils with fines composed of calcigel bentonite, in which a significant amount of the pore water will be strongly bounded to the surface of the clay particles. Since there is more free pore water in the sand-kaolin mixtures, and generally a larger void space at same relative density, the soil fabric is more collapsible and excess pore water pressures can thus more easily develop. This agrees well with the tendencies in Fig. 11.

\section{Conclusions}

A series of undrained monotonic triaxial tests was conducted on clean Hostun sand and Hostun sand mixed with different amounts of two different clays, kaolin and calcigel bentonite. The plasticity index and the specific surface of calcigel are much larger than for kaolin. The results show that for both types of clay, the response becomes more contractive and thus the mobilized deviatoric stresses decrease with increasing clay content. Furthermore, for the same clay content and at a similar relative density, the specimens containing kaolin show a more contractive behavior and lower mobilized deviatoric stresses compared to the specimens containing calcigel bentonite. The steady/critical state lines (SSLs) in the $e-p$ ' space are shifted downwards with increasing clay content. The SSLs of the mixtures with $10 \%$ and $20 \%$ kaolin showed a similar slope as that of the clean Hostun sand. The SSLs for the mixtures with $10 \%$ and $20 \%$ calcigel showed flatter or steeper inclinations compared to the host sand, respectively, with the latter possibly caused by an exceedance of the threshold fines content. The inclination of the steady/critical state in the $q-p^{\prime}$ diagram was found independent of clay type and clay content. An analysis of the instability points showed that sand containing kaolin is more susceptible to flow liquefaction than sand containing calcigel.

Funding Open Access funding enabled and organized by Projekt DEAL.
Open Access This article is licensed under a Creative Commons Attribution 4.0 International License, which permits use, sharing, adaptation, distribution and reproduction in any medium or format, as long as you give appropriate credit to the original author(s) and the source, provide a link to the Creative Commons licence, and indicate if changes were made. The images or other third party material in this article are included in the article's Creative Commons licence, unless indicated otherwise in a credit line to the material. If material is not included in the article's Creative Commons licence and your intended use is not permitted by statutory regulation or exceeds the permitted use, you will need to obtain permission directly from the copyright holder. To view a copy of this licence, visit http://creativecommons. org/licenses/by/4.0/.

\section{References}

1. Abichou T, Benson CH, Edil TB (2002) Micro-structure and hydraulic conductivity of simulated sand-bentonite mixtures. Clays Clay Miner 50(5):537-545

2. Agus SS, Schanz T (2008) A method for predicting swelling pressure of compacted bentonites. Acta Geotech 3(2):125

3. Ajmera B, Brandon T, Tiwari B (2017) Influence of index properties on shape of cyclic strength curve for clay-silt mixtures. Soil Dyn Earthq Eng 102:46-55

4. Andrews DCA, Martin GR (2000) Criteria for liquefaction of silty soils. In: Proceedings of the 12th world conference on earthquake engineering, Auckland, New Zealand

5. Baille W, Tripathy S, Schanz T (2010) Swelling pressures and one-dimensional compressibility behavior of bentonite at large pressures. Appl Clay Sci 3(48):324-333

6. Baldi G, Nova R (1984) Membrane penetration effects in triaxial testing. J Geotech Eng (ASCE) 110:403-420

7. Baki MAL (2011) Cyclic liquefaction behaviour of granular materials with fines, $\mathrm{PhD}$ thesis, The University of New South Wales

8. Belkhatir M, Arab A, Schanz T, Missoum H, Della N (2011) Laboratory study on the liquefaction resistance of sand-silt mixtures: effect of grading characteristics. Granular Matter 13:599-609

9. Beroya MAA, Aydin A, Katzenbach R (2009) Insight into the effects of clay mineralogy on the cyclic behavior of silt-clay mixtures. Eng Geol 106:154-162

10. Bouferra R, Shahrour I (2004) Influence of fines on the resistance to liquefaction of a clayey sand. Proc Inst Civ Eng Gr Improv $8(1): 1-5$

11. Cerato A, Lutenegger A (2002) Determination of surface area of fine-grained soils by the ethylene glycol monoethyl ether (EGME) method. Geotech Test J 25(3):315-321

12. Chu DB, Stewart JP, Lee S, Tsai JS, Lin PS, Chu BL, Seed RB, Hsu SC, Yu MS, Wang MCH (2004) Documentation of soil conditions at liquefaction and non-liquefaction sites from 1999 Chi-Chi (Taiwan) earthquake. Soil Dyn Earthq Eng 9-10:647-657

13. Collins K, McGown A (1974) The form and function of microfabric features in a variety of natural soils. Géotechnique 24(2):223-254

14. DIN18126 (1996): Baugrund, Untersuchung von BodenprobenBestimmung der Dichte nichtbindiger Böden bei lockerster und dichtester Lagerung. Germany

15. DIN 18127 (2012) Baugrund, Untersuchung von Bodenproben Proctorversuch, Germany.

16. DIN 18196 (2011): Erd- und Grundbau - Bodenklassifikation für bautechnische Zwecke, Germany. 
17. Georgiannou VN, Burland JB, Hight DW (1990) The undrained behavior of clayey sands in triaxial compression and extension. Géotechnique 40(3):431-449

18. Georgiannou VN (2006) The undrained response of sands with addition of particles of various shapes and sizes. Géotechnique 56:639-649

19. Ghahremani M, Ghalandarzadeh A, Ghahremani K (2007) Laboratory investigation of the effect of plastic fines on cyclic resistance of sand-clay mixtures. In: 4th International Conference on Earthquake Geotechnical Engineering

20. Goudarzy M, Rahman MM, König D, Schanz T (2016) Influence of non-plastic fines content on maximum shear modulus of granular materials. Soils Found 56(6):973-983

21. Gratchev IB, Sassa K, Osipov VL, Sokolov VN (2006) The liquefaction of clayey soils under cyclic loading. Eng Geol 86(2006):70-84

22. Grim RE (1962) Applied clay mineralogy. McGraw-Hill, New York, p 422

23. Guo T, Prakash S (1999) Liquefaction of silts and silt-clay mixtures. J Geotech Geoenviron Eng ASCE 125(8) 706-710

24. Holzer TL, Hanks TC, Youd TL (1989) Dynamics of liquefaction during the 1987 superstition hills. Calif Earthq Sci 244(4900):56-59

25. Ishihara K, Muroi T, Towhata I (1989) In-situ pore water pressures and ground motions during the 1987 Chiba-Toho-Oki earthquake. Soils Found 29(4):75-90

26. Ishihara K (1993) Liquefaction and flow failure during earthquakes. Géotechnique 43(3):351-415

27. Jefferies MG, Been K (2000) Implications for critical state theory from isotropic compression of sand. Géotechnique 50:419-429

28. Koester JP (1994) The influence of fine type and content on cyclic strength, ground failures under seismic conditions, ASCE Geotechnical Special Publication No. 44, 17-33

29. Kuerbis RH, Negussey D, Vaid YP (1988) Effect of gradation andfinescontent on the undrained response of sand. Proc ASCE Conf Hyd Fill Struct Geotech Spec Pub 21:330-345

30. Kuwano J, Imura H, Takahara K, Nakazawa H (1995) Undrained cyclic and monotonic behavior of sand-kaolin mixture. Earthq Geotech Eng Conf, 165-171, Balkema, Rotterdam, ISBN: 90 58091163

31. Lade PV, Pradel D (1990) Instability and plastic flow of soils. I: experimental observations. J Eng Mech 116(11):2532-2550

32. Lade PV, Yamamuro JA (1997) Effects of nonplastic fines on static liquefaction of sands. Can Geotech J 34:918-928

33. Lashkari A (2014) Recommendations for extension and re-calibration of an existing sand constitutive model taking into account varying non-plastic fines content. Soil Dyn Earthq Eng 61-62:212-238

34. Lashkari A (2016) Prediction of flow liquefaction instability of clean and silty sands. Acta Geotech 11:987-1014. https://doi.org/ 10.1007/s11440-015-0413-9

35. Li XS, Wang Y (1998) Linear representation of steady-state line for sand. J Geotech Geoenviron Eng 124(12):1215-1217

36. Meier LP, Kahr G (1999) Determination of the cation exchange capacity (CEC) of clay minerals using the complexes of copper(II) ion with triethylenetetramine and tetraethylenepentamine. Clays Clay Miner 47:386-388

37. Miura S, Kawamura S, Yagi K (1995) Liquefaction damage of sandy and volcanic grounds in the 1993 Hokkaido Nansei-Oki earthquake In: Proceedings: Third International Conference on Recent Advances in Geotechnical Earthquake Engineering and Soil Dynamics, St. Louis, Missouri

38. Monkul MM, Yamamuro JA (2011) Influence of silt size and content on liquefaction behavior of sands. Can Geotech J 48:931-942
39. Nabeshima Y, Matsu T (2003) Role of plastic and non-plastic fines on cyclic shear behavior of saturated sands. In: Proceedings of the Thirteenth International Offshore and Polar Engineering Conference, $\mathrm{p}$ 440-444

40. Nicholson PG, Seed RB, Anwar HA (1993) Elimination of membrane compliance in undrained triaxial testing-I: measurement and evaluation. Can Geotech J 30(5):727-738

41. Ni Q, Tan TS, Dasari GR, Hight DW (2004) Contribution of fines to the compressive strength of mixed soils. Geotechnique 54(9):561-569

42. Omar T, Sadrekarimi A (2014) Effects of multiple corrections on triaxial compression testing of sands. J GeoEng 9(2):75-83

43. Papadopoulou AI, Tika TM (2016) The effect of fines plasticity on monotonic undrained shear strength and liquefaction resistance of sands. Soil Dyn Earthq Eng 88:191-206

44. Park SS, Kim YS (2013) Liquefaction resistance of sands containing plastic fines with different plasticity. J Geotech Geoenviron Eng 139(5):825-830

45. Perlea VG, Koester JP, Prakash S (1999) How Liquefiable are cohesive soils? In: Proceedings of second international conference on earthquake geotechnical Engineering, Lisbon, Portugal, Vol. 2, 611-618

46. Perlea VG (2000) Liquefaction of cohesive soils. In: Proceedings of sessions of Geo-Denver: 2000, ASCE Geotechnical Special publication, No. 107, 58-76

47. Polito CP (1999) The effect of non-plastic and plastic fines on the liquefaction of sandy soils, $\mathrm{PhD}$ Thesis, Virginia Polytechnic Institute and State University

48. Polito CP, Martin JR (2001) Effects of nonplastic fines on the liquefaction resistance of sands. J Geotech Geoenviron Eng 27(5):408-415

49. Porcino DD, Diano V, Triantafyllidis T, Wichtmann T (2020) Predicting undrained static response of sand with non-plastic fines in terms of equivalent granular state parameter. Acta Geotech 15:867-882. https://doi.org/10.1007/s11440-019-00770-5

50. Pusch R, Yong RN (2006) Microstructure of smectite clays and engineering performance. Taylor \& Francis, London

51. Rahman MM, Lo SR (2008) The prediction of equivalent granular steady state line of loose sand with fines. Geomech Geoeng 3(3):179-190. https://doi.org/10.1080/17486020802206867

52. Rahman MM, Lo SR, Baki MAL (2011) Equivalent granular state parameter and undrained behavior of sand-fines mixtures. Acta Geotech 6:183-194. https://doi.org/10.1007/s11440-011-0145-4

53. Rahman MM, Baki MAL, Lo SCR (2014) Prediction of undrained monotonic and cyclic liquefaction behavior of sand with fines based on the equivalent granular state parameter. Int $\mathbf{J}$ Geomech 14(2):254-266

54. Salgado R, Bandini P, Karim A (2000) Shear strength and stiffness of silty sand. J Geotech Geoenviron Eng 126(5):451-462

55. Sarkar D, König D, Goudarzy M (2019) The influence of particle characteristics on the index void ratios ingranular materials. Particuology 46:1-13. https://doi.org/10.1016/j.partic.2018.09.010

56. Sarkar D, Goudarzy M, König D (2019) An interpretation of the influence of particle shape on the mechanical behavior of granular material. Granul Matter 21:53. https://doi.org/10.1007/ s10035-019-0909-3

57. Schofield A, Wroth CP (1968) Critical state soil mechanics, New York: McGraw-Hill, pp 1-310

58. Seed HB, Idriss IM, Arango I (1983) Evaluation of liquefaction potential using field performance data. J Geotech Eng 109(3):458-482

59. Tao M, Figueroa JL, Saada AS (2004) Influence of nonplastic fines content on the liquefaction resistance of soils in terms of the unit energy. In: Proceedings of the cyclic behavior of soils and liquefaction phenomena, Bochum, Germany: A. A. Balkema publishers 
60. Tatsuoka F, Toki S, Miura S, Kato H, Okamoto M, Yamada S, Yasuda S, Tanizawa F (1986) Some factors affecting cyclic undrained triaxial strength of sand. Soils Found 26(3):99-116

61. Thevanayagam S (1998) Effect of fines and confining stress on undrained shear strength of silty sands. J Geotech Geoenviron Eng ASCE 124(6):479-491

62. Thevanayagam S, Shenthan T, Mohan S, Liang J (2002) Undrained fragility of clean sands, silty sands, and sandy silts. J Geotech Geoenviron Eng 128(10):849-859

63. Tsai PH, Lee DH, Kung GTC, Hsu C-H (2010) Effect of content and plasticity of fines on liquefaction behavior of soils. Q J Eng Geol Hydro Geol 43(1):95-106

64. Vahidi-Nia F, Lashkari A, Binesh SM (2015) An insight into the mechanical behavior of granular soils. Particuology 21:82-89

65. Vaid YP, Chern JC (1985) Cyclic and monotonic undrained response of sands. In: Advances in the art of testing soils under cyclic loading conditions, proceedings of the ASCE convention, New York, USA, pp 120-147
66. Xenaki VC, Athanasopoulos GA (2003) Liquefaction resistance of sand-silt mixtures: an experimental investigation of the effect of fines. Soil Dyn Earthq Eng 23(3):1-12

67. Yang J, Wei LM (2012) Collapse of loose sand with the addition of fines: the role of particle shape. Geotechnique 62(12):1111-1125

68. Yang J, Liu X (2016) Shear wave velocity and stiffness of sand: the role of non-plastic fines. Geotechnique 66(6):500-514

69. Yin ZY, Zhao J, Hicher PY (2014) A micromechanics-based model for sand-silt mixtures. Int J Solids Struct 51:1350-1363

70. Zlatovic S, Ishihara K (1995) On the influence of nonplastic fines on residual strength. In: Proceedings of the 8th world conference on earthquake engineering, Tokyo, 14-16

Publisher's Note Springer Nature remains neutral with regard to jurisdictional claims in published maps and institutional affiliations. 